\title{
WILEY-VCH
}

DOI: $10.1002 /$

Article type: Full Paper

\section{2-D Crystals Significantly Enhance the Performance of a Working Fuel Cell}

Stuart M. Holmes*, Prabhuraj Balakrishnan, Vasu. S. Kalangi, Xiang Zhang, Pulickel M. Ajayan, Marcelo Lozada-Hidalgo and Rahul R. Nair

Dr. S.M. Holmes, P. Balakrishnan

School of Chemical Engineering and Analytical Science, The University of Manchester, Manchester, M13 9PL, UK.

Email: stuart.holmes@manchester.ac.uk

Dr. R. R. Nair, Dr. V. S. Kalangi

National Graphene Institute and School of Chemical Engineering and Analytical Science, the University of Manchester, Manchester, M13 9PL, UK.

Dr. M. Lozada-Hidalgo

School of Physics and Astronomy, The University of Manchester, Manchester, M13 9PL, UK. Dr. P. M. Ajayan, X. Zhang

Department of Materials Science and NanoEngineering, Rice University, 6100 Main, MS321, Houston, Texas 77005-1892, USA.

Keywords: fuel cells, CVD, graphene, methanol, hBN

Two-dimensional atomic crystals such as single layer graphene (SLG) and hexagonal boron nitride (hBN) have been shown to be "unexpectedly permeable" to hydrogen ions ${ }^{[1]}$ under ambient conditions with the proton conductivity rising exponentially with temperature. Here we show the first succesful addition of SLG made by a chemical vapour deposition (CVD) method to an operational direct methanol fuel cell (DMFC) significantly enhancing the performance of the cell once the temperature is raised above $60^{\circ} \mathrm{C}$, the temperature at which the proton conductivity of SLG is higher than the Nafion membrane on which it is mounted. Above this temperature, the resistance to proton transport of the system is not affected by the graphene but the barrier properties of graphene inhibit methanol crossover. The performance of the fuel cell is shown to increase linearly with coverage of SLG above this temperature. Results show that the maximum power density is increased at $70^{\circ} \mathrm{C}$ by $45 \%$ in comparison to the standard membrane electrode assembly (MEA) without graphene. In addition, a 


\section{WILEY-VCH}

membrane with CVD hBN shows enhanced performance across the entire temperature range due to better proton conductivity at lower temperatures.

\section{Introduction}

Recent research on proton conductivity through 2D atomic crystals shows great potential in hydrogen based technology such as fuel cells. ${ }^{[1,2]}$ Fuel cells have a significant role in energy generation due to their high energy density and ease of maintenance and operation. ${ }^{[3-5]}$ These electrochemical devices convert the chemical energy of fuels (hydrogen, methanol, ethanol, glycerol and others) directly into electricity by reacting with an oxidant (air or oxygen). ${ }^{[3-7]}$ Direct Methanol Fuel Cells (DMFCs) are attractive because of the physical properties of methanol being a liquid fuel with high energy density (when compared to hydrogen gas), hence offering advantages in transportation and storage. ${ }^{[4,6,7]}$ In general, open circuit voltage $(\mathrm{OCV})$ in normal operation of a DMFC is around $0.8 \mathrm{~V}$ which is far lower than the theoretical voltage of $1.20 \mathrm{~V}$ (defined by its half-cell reactions). ${ }^{[3,4,6]}$ This is caused by several factors, of which fuel passing through the membrane to the cathode is a significant contribution. Methanol crossover is a significant hindrance to DMFC commercialisation, which degrades the cell performance and durability due to permeation of methanol driven by the combined effect of diffusion and electro-osmotic drag. ${ }^{[6-9]}$ Oxidation of permeated methanol at the cathode in the presence of catalyst leads to mixed-potential and short-circuit thereby degrading fuel cell performance. ${ }^{[6-8]}$

The problem of methanol crossover can be partially addressed by an operational strategy of adjusting the feed concentration depending on the current density required, an approach which has been pioneered by MTI fuel cells Ltd in the US. ${ }^{[10,11]}$ Increasing the partial pressure of oxygen at the cathode increases cell performance, due to the reduction in activation overpotential at the cathode. In addition, it has been demonstrated that the increase of pressure at the cathode further reduces the rate of methanol permeation, therefore improves the fuel 


\section{WILEY-VCH}

cell performance. ${ }^{[6,8,12,13]}$ However, both operational approaches require additional balance of plant, greater complexity and in the case of dilution, increased fuel reservoir volume.

Currently, Nafion is widely used as the polymer electrolyte membrane in fuel cell systems because of its excellent proton conducting properties and stable structure under fuel cell operating conditions. ${ }^{[14,15,16]}$ However, degradation of the DMFC performance due to methanol diffusion through Nafion membrane demands the need for a barrier layer. ${ }^{[7,8]} \mathrm{A}$ great deal of research has been carried out to reduce methanol crossover by using Nafion composites with organophobic moieties. ${ }^{[14-17]}$

Unique properties like high proton conductivity and an exceptional impermeability to all gases and molecules, coupled with stability in humid oxygen up to $400^{\circ} \mathrm{C}$, have identified SLG and hBN as possible barrier materials to avoid methanol crossover without degrading the fuel cell performance. This is attributed to the dense lattice structure of highly crystalline 2D graphene, blocking molecules and atoms including hydrogen ${ }^{[18,19]}$. Recently, Yan et. al. have applied this concept to a passive DMFC demonstrating impediment of methanol but reduced proton conductivity as would be expected operating at room temperature. ${ }^{[20]}$ However, active DMFCs are widely targeted due to their enhanced power output. Hence in this work, active methanol systems are tested for the first time at elevated temperature, showing significant improvement in performance.

A barrier layer is a simple approach to impede methanol permeation and help in effective utilization of methanol on the anode side thereby increasing the performance. ${ }^{[9,13,21]}$ It is essential however, that the proton conductivity is not reduced significantly as the two mechanisms do not scale linearly, ${ }^{[22]}$ and loss of proton conductivity even with greatly enhanced methanol barrier properties will significantly reduce the efficacy of the fuel cell. ${ }^{[23]}$ Hence a balance should normally be made between proton conductivity and methanol repulsion properties when incorporating a barrier layer. 


\section{WILEY-VCH}

While Geim et al. ${ }^{[1]}$ have demonstrated proton transport through single layer graphene and $\mathrm{hBN}$ flakes, this effect relies on a coherent sheet of the 2D material to ensure no transport of hydrogen across the 'membrane, and this proof of concept has only been carried out using a $50 \mu \mathrm{m}$ area. Furthermore, the work on 'Proton Transport through One Atom Thick Crystals' used ionised water as a proton source over very short timescales, as such the work was not representitive of both the conditions or the timescales needed in a working system. These limitations are impractical for a working fuel cell system, however, by incorporating CVD graphene or hBN into the membrane of an active direct methanol fuel cell for the first time, the benefits of the proton transport can be utilised without the need for fabricating large scale, defect free, sheets of single layer graphene and hBN. This is due to the $2 \mathrm{D}$ material increasing the tortuosity (path length) of the methanol transport across the membrane while the protons can pass through the graphene or hBN without deviation. As the methanol and proton transport are competing processes, the increased path length for the methanol means that less of the fuel crosses the membrane and hence the fuel cell performance is enhanced. Clearly, the fewer defects in the 2D barrier, the greater the tortuosity for the methanol and hence the greter the enhancement of the fuel cell performance.

In this work, we show the increased power density for a DMFC system where an atomically thin CVD graphene or hBN film is used as a barrier coating to avoid methanol crossover without affecting the proton conductivity. SLG is used in this work, as bi-layer and multilayer graphene has been shown to demonstrate no proton transport ${ }^{[1]}$. The DMFC system with a single layer CVD hBN coated MEA has shown higher proton conductivity across the temperature range tested $\left(30-90^{\circ} \mathrm{C}\right)$ whereas a DMFC with a single layer CVD graphene coated MEA has shown improved performance at or above $60^{\circ} \mathrm{C}$ since the work by Geim demonstrated that SLG only achieves proton conductivity higher than Nafion at temperatures greater than $50^{\circ} \mathrm{C}$. This work also shows for the first time the link between SLG coverage and DMFC performance demonstrating that the greater the area of single layer graphene (vs defect 


\section{WILEY-VCH}

or multi layer) in the MEA the lower the methanol crossover and hence the greater the enhancement to the DMFC performance.

\section{Results and Discussion}

\subsection{Cell performance}

Generally, a Nafion based DMFC system operates in the temperature range of $30^{\circ} \mathrm{C}$ to $90^{\circ} \mathrm{C}$ using $1 \mathrm{M}$ methanol and air as fuel and oxidant (experimental set up given in Figure 1a) as the Nafion begins dehydrate above $90^{\circ} \mathrm{C}$ and becomes ineffective as a proton conductor. To characterise the membrane, we have studied proton conductivity, methanol permeability and performance in an operational fuel cell. Figure $1 \mathrm{~b}$ shows the polarization curves obtained at $70^{\circ} \mathrm{C}$ with standard MEA and CVD SLG coated MEA. It is apparent that a significant increase in power density from $53 \pm 1 \mathrm{~mW} / \mathrm{cm}^{2}$ to $77 \pm 1 \mathrm{~mW} / \mathrm{cm}^{2}$ is obtained with SLG coated MEA. Higher Open Circuit Voltage (OCV) is a good indicator of reduced methanol cross over since the methanol molecules which are prevented from passing through the membrane

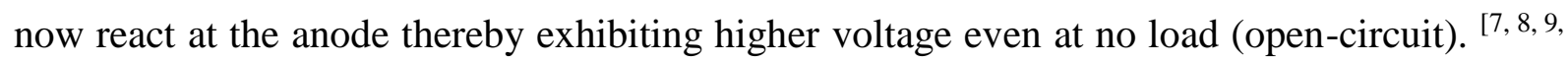
${ }^{13]}$ It can be seen from the inset of figure $1 \mathrm{~b}$ that the OCV of the MEA with SLG at $70^{\circ} \mathrm{C}$ and $1 \mathrm{M}$ methanol conditions is $0.668 \mathrm{~V}$ whereas the standard is $0.625 \mathrm{~V}$ which indicates that methanol cross-over has been reduced. Results over the complete temperature range are available in the supporting information. The electrochemically active surface area of the MEA containing SLG or hBN is expected to be the same as the standard since the catalyst layer and MEA manufacture technique are the same giving an equivalent electrode with a barrier layer between the Nafion and the catalyst.

The methanol permeability results measured using linear sweep voltammetry, reveal that the amount of methanol crossover has decreased from $3.14 \times 10^{-6} \mathrm{~cm}^{2} / \mathrm{s}$ (for the standard) to 2.19 $\mathrm{x} 10^{-6} \mathrm{~cm}^{2} / \mathrm{s}$ for an MEA with SLG as a barrier layer at $70^{\circ} \mathrm{C}$ and $1 \mathrm{M}$ methanol (figure $\mathrm{S} 1$ ). As a result of reduction in methanol cross over, fuel utilization increases at the anode and the 


\section{WILEY-VCH}

blocked methanol molecules retained at the anode catalyst layer react. $[8,9,24]$ This is evidenced by the higher current for the methanol oxidation reaction (MOR) of $345 \pm 3$ $\mathrm{mA} / \mathrm{cm}^{2}$ for the MEA with SLG compared to $200 \pm 3 \mathrm{~mA} / \mathrm{cm}^{2}$ for the standard (figure S2) when measured by cyclic voltammetry. Further, we attribute the increase in peak curent intensity and decreased methanol oxidation onset potential $(50 \mathrm{mV}$ lower in comparison to the standard MEA) to an enhancement of the charge transfer rate in the case of MEA with $\operatorname{SLG}^{[25,26]}$.

Although this barrier layer has significantly decreased the methanol permeability and helped in improving the performance, no reduction in proton conductivity is observed from the impedance spectroscopy measurements obtained at $70^{\circ} \mathrm{C}$ in $1 \mathrm{M}$ methanol and $1 \mathrm{~L} / \mathrm{min}$ of air (figure S3 and S4).

\subsection{Extended performance testing}

It is important that the lifetime of an MEA is assessed when a new process is developed, as short term improvements can often be seen but are sometimes followed by a rapid drop in the performance. ${ }^{[24,27]}$ While long term durability testing is beyond the scope of this work, durability tests have been carried out at low current density and high current density regions to evaluate the membrane stability in comparison with the standard MEA.

Testing in the low current density region at $50 \mathrm{~mA} / \mathrm{cm}^{2}$, provided a constant voltage of 0.540 $\mathrm{V}$ (MEA with SLG) compared to $0.450 \mathrm{~V}$ (standard) at a loss of around $5 \mathrm{mV}$ over a 24 hour period (uninterrupted loading) indicating similar stability of the SLG MEA when compared to the standard (figure S5). ${ }^{[24,27]}$ Testing at higher current density where accelerated degradation occurs (370 $\mathrm{m} \mathrm{A} / \mathrm{cm}^{2}$ for the standard and $475 \mathrm{~mA} / \mathrm{cm}^{2}$ for SLG-Sample E), again indicates that the voltage profile of the MEA with SLG is very similar to standard (figure S6), showing comparable stability to Nafion even at these high current density regions. ${ }^{[27,28]}$ It was found that the degradation was reversible for both SLG and standard MEA's using air starvation 


\section{WILEY-VCH}

mode (a cell performance recovery method) conditioning of the MEA's which led to a complete recovery of cell voltage. ${ }^{[29]}$

\subsection{Effect of deposition on performance (different samples)}

As described in the experimental section, SLG is deposited onto the fuel cell electrodes by transferring from $\mathrm{Cu}$ foil. During the transfer process, the defects and cracks which occur in the SLG cause a difference in graphene coverage on different electrodes. ${ }^{[30]}$ As a result, it has been found that samples showed different improvement in performance, as given in figure $2 \mathrm{a}$. The main difference in Sample A to Sample E in Figure $2 a$ and $2 b$ is the graphene coverage on the anode electrode surface. Our Raman measurements corroborate the electrochemical experiments revealing that Sample A has the least ( 40\%) and Sample E has the highest ( $60 \%$ ) graphene coverage at the anode. Coverage was evaluated by Optical microscopy (figure S7) and Raman spectroscopy (figure S8), as other analysis, Energy dispersive X-ray spectroscopy (EDAX) and X-ray photoelectron spectroscopy (XPS) predominantly shows the amorphous carbon signal rather than the crystalline graphene/hBN.

Raman spectroscopy was carried out over $50 \mu \mathrm{m}$ x $50 \mu \mathrm{m}$ area at laser excitation of $514 \mathrm{~nm}$ to obtain information about graphene coverage on the electrodes. The spectra collected from Sample E shows the highest number of spots corresponding to SLG, whereas the Sample A has the least number of SLG spots, which is in accordance with the microscope images (figure S7) and is directly related to performance shown in figure $2 b$.

\subsection{Effect of temperature}

Geim et.al have shown that proton conductivity of graphene increases exponentially as temperature of operation rises from $30^{\circ} \mathrm{C}$ to $70^{\circ} \mathrm{C}$. ${ }^{[1]}$ A study of the effect of temperature on the properties described above was carried out to demonstrate this effect in a DMFC (figure 3). Interplay between proton conductivity and methanol permation regulates the maximum power density of DMFC. It is apparent that from $50^{\circ} \mathrm{C}$ (Figure. 3), the maximum power density values for DMFC with SLG coated MEA are increased in comparison to the standard DMFC. 


\section{WILEY-VCH}

At the lower temperatures (below $50^{\circ} \mathrm{C}$ ), the resistance to protons in graphene has a detrimental effect and the reduced methanol permeability cannot compensate for this poor conductivity. However, above $60^{\circ} \mathrm{C}$ the proton conductivity of graphene increases significantly and hence the proton conductivity of MEA with SLG A matches with that of standard MEA from $60^{\circ} \mathrm{C}$ onwards. Notably, DMFC with an SLG coated MEA has shown $45 \%$ imporvement in the manximum power density at $70^{\circ} \mathrm{C}$ in comparison to the DMFC with standard MEA. The increased maximum power density is attributed to the reduced methanol permeability in DMFC with graphene coated MEA (in comparison to the standard DMFC) where CVD grown monolayer graphene is deposited onto the anode carbon electrode. Figure 4 shows that that methanol crossover has been reduced at all temperatures, owing to the dense lattice structure of SLG. However, the proton resistance of SLG plus Nafion is higher than Nafion standard as the temperature falls below $60^{\circ} \mathrm{C}^{[1]}$ The non-linear relationship between the effect of methanol crossover and proton conductivity, ${ }^{[22]}$ means that proton conductivity is the dominant factor in determining the overall performance. This is refelcted in the maximum power densities obtained during the effect of temperature study (figure 3 ). It is clear from Figure 3 that at $60^{\circ} \mathrm{C}$ and $50^{\circ} \mathrm{C}$ the slightly lower proton conductivity is offset by the reduced methanol crossover whereas at $40^{\circ} \mathrm{C}$ and $30^{\circ} \mathrm{C}$, the loss in proton conductivity is large enough to reduce performance below that of the standard.

Figure 4 shows that above $60^{\circ} \mathrm{C}$ the proton conductivity of the MEA is unaffected by the presence of CVD graphene but that methanol permeability is reduced producing an enhanced performance. Methanol permeability was further estimated using gravimetric measurements (figure S9). Permeation of methanol is calculated from the weight loss measurements of a metal container sealed with the fuel cell MEA with and without SLG. Figure S9 shows the weight loss of a methanol filled metal container with an aperture covered with the fuel cell MEA (area $\sim 2 \mathrm{~cm}^{2}$ ) with and without SLG. We found that the evaporation rate of methanol, calculated from the measured weight loss, through the fuel cell MEA with SLG $(\sim 0.72$ 


\section{WILEY-VCH}

$\mathrm{mg} / \mathrm{h} / \mathrm{mm}^{2}$ ) is $32 \%$ lower than the methanol permeation rate though the fuel cell electrode without SLG $\left(\sim 1.06 \mathrm{mg} / \mathrm{h} / \mathrm{mm}^{2}\right)$. This is in good agreement with the methanol permeability values calculated from linear sweep voltammetry (along with the power density, and proton resistance, Figures S10, 11 and 12) where we have observed 26\% lower methanol permeability for the fuel cell electrode with SLG in comparison to fuel cell electrode without SLG. A defect-less and highly crystalline graphene monolayer is impermeable to methanol molecules, however, the transfer-induced defects, folding and cracks meaning the barrier reduces but does not stop the methanol permeation through the fuel cell electrode with SLG.

\section{5. hBN barrier layer}

A preliminary study with CVD hexagonal Boron Nitride $(\mathrm{hBN})$ has shown higher maximum power densities, than the standard, at all temperatures (Figure 5a), with hBN sample C showing 18\% improvement (Figure S13). Similar barrier properties to SLG for the inhibition of methanol crossover were noted at all temperatures (Figure 5b). Comparing the methanol permeabilities with the single layer graphene data (Figure S10 and S15), it is clear that the coverage is poor in this hBN sample C (lower than SLG sample A). However, Figure 5c indicates that there is no additional proton resistance from the hBN even at low temperatures due to higher proton conductivity of single layer hBN. Different hBN samples showed varied improvement in performance, owing to the difference in surface coverage of $\mathrm{hBN}$ on fuel cell electrode. The power performance (Figure S14) and their corresponding membrane characterization results of different hBN samples (Figure S15, S16 and S17), confirm the promising nature of $\mathrm{hBN}$ as a barrier layer. Also methanol half cell studies of hBN show enhanced charge transfer characteristics, in the same way as SLG as evidenced by decreased methanol onset potential, around $50 \mathrm{mV}$ lower as given in the figure $\mathrm{S} 18$.

\section{Conclusion}




\section{WILEY-VCH}

In conclusion, addition of the graphene layer has significantly changed the properties of the MEA by reducing the methanol permeability with no measurable difference in proton conductivity at elevated temperatures. In supporting the conclusion from earlier work, ${ }^{[1]}$ though the graphene transferred onto the electrode contains fractures and defects, it still provides greater tortuosity for the methanol while the protons are completely unaffected by the graphene. A DMFC with a graphene coated anode electrode has shown enhanced performence in the temepreature range from $50{ }^{\circ} \mathrm{C}$ to $90{ }^{\circ} \mathrm{C}$, while $\mathrm{hBN}$ is enhanced across the whole temperature range. It is apparent that the quality of large grain CVD graphene over the MEA area enhances the cell performance and the potential for a coherent film giving the 'perfect' DMFC membrane is a real prospect. This would lead to highly efficient, smaller and less complicated DMFC systems with thinner Nafion membranes and reduced ohmic resistance, coupled with less dilution of methanol feed and/or reduced air pressure at the cathode. Preliminary hBN results show a similar effect but the enhanced proton conductivity, even at low temperatures, indicates that a fuel cell containing coherent single layer hBN would be more effective over the entire temperature range.

\section{Experimental Section}

\section{MEA preparation:}

Carbon ink (containing ketjen black with $10 \mathrm{wt} \%$ PTFE dissolved in isopropanol) sprayed onto the gas diffusion layer (GDL, carbon paper TGPH 090, 280 micron) of area $2.25 \mathrm{~cm}^{2}$ forms the micro-porous layer (MPL) with a loading of $1 \mathrm{mg} / \mathrm{cm}^{2}$ of ketjen black after sintering in oven at $300^{\circ} \mathrm{C}$ for 3 hours. A catalyst ink containing $15 \mathrm{wt} \%$ Nafion ionomer with catalyst (60 wt\% Pt:Ru on Vulcan XC-72 for anode and 60 wt\% Pt on Vulcan XC-72 for cathode) dissolved in acetone is then sprayed onto the MPL giving a loading of $1 \mathrm{mg} / \mathrm{cm}^{2}$ of Pt on both electrodes and $0.5 \mathrm{mg} / \mathrm{cm}^{2}$ of Ru on anode. Nafion 117 membrane (pre-treated by heating in de-ionized water, $30 \mathrm{wt} \%$ hydrogen peroxide and $1 \mathrm{M}$ sulphuric acid solutions at 


\section{WILEY-VCH}

$80^{\circ} \mathrm{C}$ each for an hour and stored in de-ionized water) is placed between the two electrodes and assembled in fuel cell test system for testing. No water cycling procedure is carried out since the membrane is already hydrated. The cell was activated at $70^{\circ} \mathrm{C}$ by air starvation mode followed by passing $1 \mathrm{M}$ methanol $(50 \mathrm{~mL} / \mathrm{min})$ and $1 \mathrm{~L} / \mathrm{min}(2 \mathrm{bar})$ of air till the optimum steady state performance is reached as shown by a stable polarization curve. ${ }^{[29]}$

\section{CVD graphene deposition:}

As-prepared chemical vapour deposition (CVD) grown graphene layer on $\mathrm{Cu}$ (of size $25 \mathrm{~mm}$ $\times 25 \mathrm{~mm}$ ), purchased from BGT Materials LTD., was spin coated with PMMA to provide the support for graphene after etching the $\mathrm{Cu}$ metal. As reported by Vasu et al. ${ }^{[31]}, 0.1 \mathrm{M}$ ammonium persulphate aqueous solution was used to etch away $\mathrm{Cu}$ metal to detach the CVD graphene. The detached graphene-PMMA layer was washed in deionised water before transferring onto the amorphous carbon electrode. A floating graphene-PMMA layer in a water bath was transferred onto the electrode by raising the electrode from beneath the floating graphene, the electrode was then dried at room temperature to remove the excess water. After drying, the PMMA layer was washed away by gently rinsing in acetone and IPA. The same transfer procedure is followed for transferring CVD grown hBN onto the MEA electrodes as for CVD graphene.

Synthesis of hBN films was carried out on the $\mathrm{Cu}$ foil using an established CVD technique as reported ${ }^{[32,33]}$.

Briefly, a copper foil with $25 \mu \mathrm{m}$ thickness was washed using nitric acid/deionized water and placed in the center of a furnace, annealed at $600{ }^{\circ} \mathrm{C}$ for $20 \mathrm{~min}$ in $\mathrm{Ar} / \mathrm{H} 2(15 \mathrm{vol} \% \mathrm{H} 2,85$ vol $\%$ argon) flow. Subsequently, the furnace was gradually heated up to $1000{ }^{\circ} \mathrm{C}$ in $40 \mathrm{~min}$. Ammonia borane (NH3-BH3) was sublimated at $120-130{ }^{\circ} \mathrm{C}$ by using a heating belt and then carried into the reaction region by $\mathrm{Ar} / \mathrm{H}_{2}$ gas glow. During the growth process, $\mathrm{Ar} / \mathrm{H}_{2}$ flow was kept as $200 \mathrm{sccm}$. The typical growth time is 30-60 min. After growth, the furnace was cooled down to room temperature quickly. 


\section{WILEY-VCH}

\section{CVD graphene characterization:}

Optical microscopy images are obtained by Axio Lab.A1 microscope to analyse the surface morphology of electrodes coated with SLG. Raman plots were obtained with Thermoscientific Raman Spectrometer at a wavelength of $514 \mathrm{~nm}$ to confirm the presence of SLG on electrodes.

\section{Measurements and Techniques:}

Fuel cell polarization curves were obtained by linear sweep voltammetry (LSV) in potentiostatic mode by scanning from $\mathrm{OCV}$ to $0 \mathrm{~V}$ at a scan rate of $0.25 \mathrm{mV}$ per second.

Methanol permeability was obtained by LSV in potentiostatic mode by scanning the working electrode potential (cathode) from 0 to $1 \mathrm{~V}$ against counter and reference electrodes (anode) at a scan rate of $5 \mathrm{mV}$ per second by passing methanol $(50 \mathrm{~mL} / \mathrm{min})$ on the anode side and dry nitrogen $(1 \mathrm{~L} / \mathrm{min}$ and 2 bar pressure) on the cathode side. The limiting current (appearance of plateau above $0.6 \mathrm{~V}$, where methanol oxidation generally takes place) is converted into methanol permeability using Faraday's law. ${ }^{[34,35]}$

Proton resistance of membrane was obtained by using impedance spectroscopy (potentiostatic). This is carried out in general fuel cell operating conditions at $0.4 \mathrm{~V}$ in frequency range from $20 \mathrm{kHz}$ to $0.01 \mathrm{~Hz}$ at amplitude of $10 \mathrm{mV}$. Proton resistance is then obtained from $\mathrm{X}$-axis intercept of impedance plot. ${ }^{[36,37-42]}$

Methanol oxidation reaction (MOR) is used to characterize the anode of the MEA to test the extent of anode reaction and is obtained by cyclic voltammetry (CV) technique in potentiostatic mode by scanning the anode (working electrode) potential from $0 \mathrm{~V}$ to $1 \mathrm{~V}$ at a scan rate of $10 \mathrm{mV}$ per second against cathode (counter and reference electrode). Methanol is passed on the anode side whereas dry nitrogen gas $(2 \mathrm{bar}-1 \mathrm{~L} / \mathrm{min})$ is passed on the cathode side. The maximum current obtained gives the extent of methanol oxidation reaction. ${ }^{[43]}$ 


\section{WILEY-VCH}

\section{Supporting Information}

Supporting Information is provided below.

\section{Acknowledgements}

The authors would like to thank the EPSRC - Graphene-based membranes (EPSRC grant EP/K016946/1) for financial backing for this work.

Received: ((will be filled in by the editorial staff))

Revised: ((will be filled in by the editorial staff)) Published online: ((will be filled in by the editorial staff))

\section{References}

[1] S. Hu, M. Lozada-Hidalgo, F. Wang, A. Mishchenko, F. Schedin, R. R. Nair, E. Hill, D.

Boukhvalov, M. Katsnelson, R. Dryfe, I. Grigorieva, H. Wu, A. Geim, Nature 2014, 516, 227.

[2] M. Lozada-Hidalgo, S. Hu, O. Marshall, A. Mishchenko, A. Grigorenko, R. Dryfe, B. Radha, I. Grigorieva, A. Geim, Science 2015, 351,68 .

[3] R. O'Hayre, Fuel Cell Fundamentals, John Wiley \& Sons, Hoboken, NJ 2006.

[4] W. Vielstich, A. Lamm, H. Gasteiger, Handbook Of Fuel Cells, Wiley, Chichester (England) 2003.

[5] K. Scott, L. Xing, Advances in Chemical Engineering 2012, 145.

[6] X. LiA. Faghri, Journal Of Power Sources 2013, 226, 223.

[7] A. Heinzel, V. Barragán, Journal Of Power Sources 1999, 84, 70.

[8] S. Song, W. Zhou, W. Li, G. Sun, Q. Xin, S. Kontou, P. Tsiakaras, Ionics 2004, 10, 458.

[9] J. ZhangY. Wang, Fuel Cells 2004, 4, 90.

[10] W. P. Acker, G. C. McNamee, W. W. Dailey (MTI), US6761988 B1, 2000.

[11] S. Thomas, Electrochimica Acta 2002, 47, 3741.

[12] J. Cruickshank, K. Scott, Journal Of Power Sources 1998, 70, 40.

[13] W. Choi, J. Kim, S. Woo, Journal Of Power Sources 2001, 96,411 .

[14] W. Xu, T. Lu, C. Liu, W. Xing, Electrochimica Acta 2005, 50,3280 . 


\section{WILEY-VCH}

[15] P. Kundu, B. Kim, J. Ahn, H. Han, Y. Shul, Journal Of Power Sources 2007, 171, 86.

[16] Z. Liang, J. Shi, S. Liao, J. Zeng, International Journal Of Hydrogen Energy 2010, 35, 9182.

[17] Z. Wu, G. Sun, W. Jin, H. Hou, S. Wang, Q. Xiang, Journal of Membrane Science 2008, $313,336$.

[18] J. S. Bunch, S. S. Verbridge, J. S. Alden, A. M. van der Zande, J. M. Parpia, H. G. Craighead, .P. L. McEuen, Nano Letters 2008, 8, 2458.

[19] S. P. Koenig, L.Wang, J. Pellegrino, J. S. Bunch, Nature Nanotechnology 2012, 7, 728.

[20] X. Yan, R. Wu, J. Xu, Z. Luo, T. Zhao, Journal Of Power Sources 2016, 311, 188.

[21] Y. Fang, R. Miao, T. Wang, X. Wang, Pure And Applied Chemistry 2009, 81, 2309.

[22] X. Li, E. Roberts, S. Holmes, Journal Of Power Sources 2006, 154, 114.

[23] V. Silva, B. Ruffmann, H. Silva, Y. Gallego, A. Mendes, L. Madeira, S. Nunes, Journal Of Power Sources 2005, 140, 34.

[24] F. Büchi, M. Inaba, T. Schmidt, Polymer Electrolyte Fuel Cell Durability, Springer New York, New York, NY 2009.

[25] Y. Li, L. Tang, J. Li Electrochemistry Communications 2009, 11, 846.

[26] S. Woo, J. Lee, S.-K. Park , H. Kim, T. D. Chung, Y. Piao, Current Applied Physics 2015, 15, 219.

[27] W. SchmittingerA. Vahidi, Journal Of Power Sources 2008, 180, 1.

[28] S. Zhang, X. Yuan, H. Wang, W. Merida, H. Zhu, J. Shen, S. Wu, J. Zhang, International Journal Of Hydrogen Energy 2009, 34, 388.

[29] A. Kulikovsky, H. Schmitz, K. Wippermann, J. Mergel, B. Fricke, T. Sanders, D. Sauer,Journal Of Power Sources 2007, 173, 420.

[30] C. N. R. Rao, A. K. Sood, Graphene, Wiley-VCH Verlag Gmbh, Weinheim 2013. 


\section{WILEY-VCH}

[31] K. S. Vasu, E. Prestat, J. Abraham, J. Dix, R. J. Kashtiban, J. Beheshtian, J. Sloan, P.

Carbone, M. Neek-Amal, S. J. Haigh, A. K. Geim, R. R. Nair, Nature Communications 2016, 7, 10.1038/ncomms12168.

[32] L. Song, L. Ci, H. Lu, P. B. Sorokin, C. Jin, J. Ni, A. G. Kvashnin, D. G. Kvashnin, J. Lou, B. I. Yakobson,.P. M. Ajayan Nano Letters 2010, 10, 3209.

[33] L. Ci, L. Song, C. Jin, D. Jariwala, D. Wu, Y. Li, A. Srivastava, Z. F. Wang, K. Storr, L. Balicas, F. Liu, P. M. Ajayan Nature Materials 2010, 9, 430.

[34] J. Han, H. Liu, Journal Of Power Sources 2007, 164, 166.

[35] S. Mollá, V. Compañ, S. Luis Lafuente, J. Prats, Fuel Cells 2011, 11, 897.

[36] J. Mueller, P. Urban, Journal Of Power Sources 1998, 75, 128.

[37] C. Lee, H. Park, Y. Lee, R. Lee, Industrial \& Engineering Chemistry Research 2005, 44, 7617.

[38] Y. Sone, P. Ekdunge, D. Simonsson, Journal Of The Electrochemical Society 1996, 143, 1254.

[39] T. Sancho, J. Soler, M. Pina, Journal Of Power Sources 2007, 169, 92.

[40] P. Piela, R. Fields, P. Zelenay, Journal Of The Electrochemical Society 2006, 153, 1902.

[41] S. Uhm, S. Chung, J. Lee, Journal Of Power Sources 2008, 178, 34.

[42] T. Yuan, L. Pu, Q. Huang, H. Zhang, X. Li, H. Yang, Electrochimica Acta 2014, 117, 393.

[43] S. WasmusA. Küver, Journal Of Electroanalytical Chemistry 1999, 461, 14. 


\section{WILEY-VCH}

$\mathbf{a}$

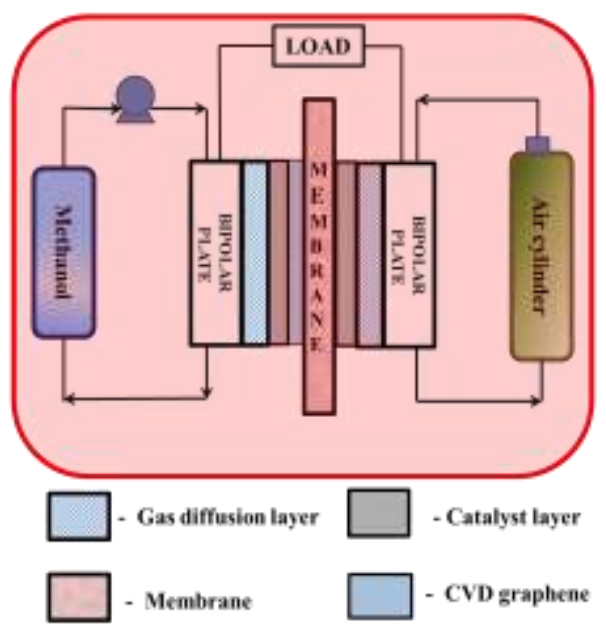

b

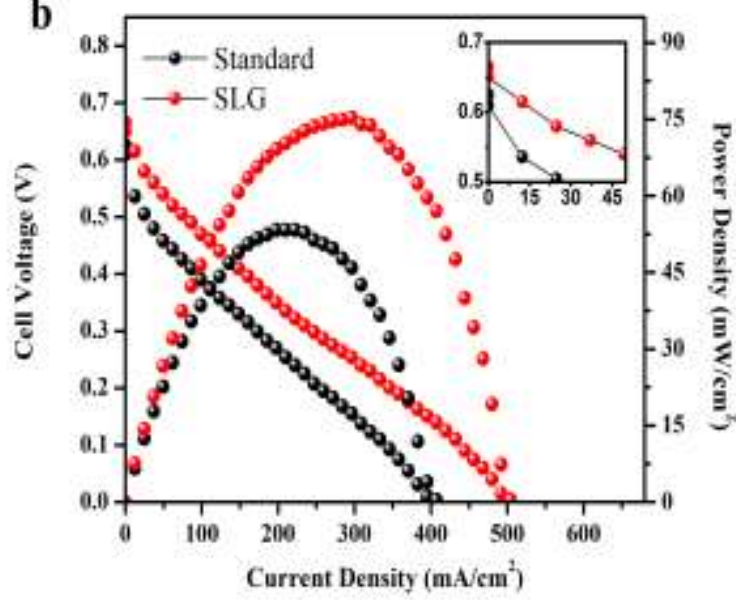

Figure 1. (a) DMFC experimental set up and MEA configuration (b) Polarization curve comparison for a standard and MEA with SLG at $70^{\circ} \mathrm{C}, 1 \mathrm{M}$ methanol, $1 \mathrm{~L} / \mathrm{min}$ of air.
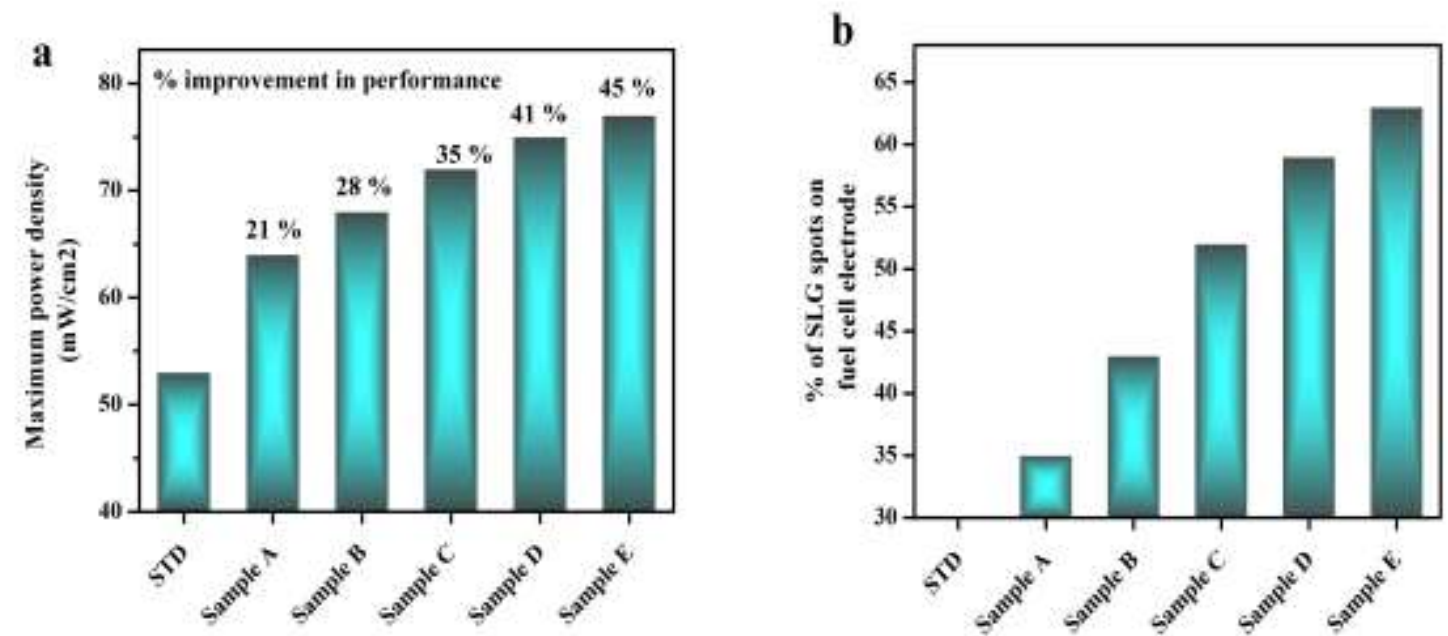

Figure 2. (a) Samples and their corresponding performance (b) \% of SLG spots for different samples. 


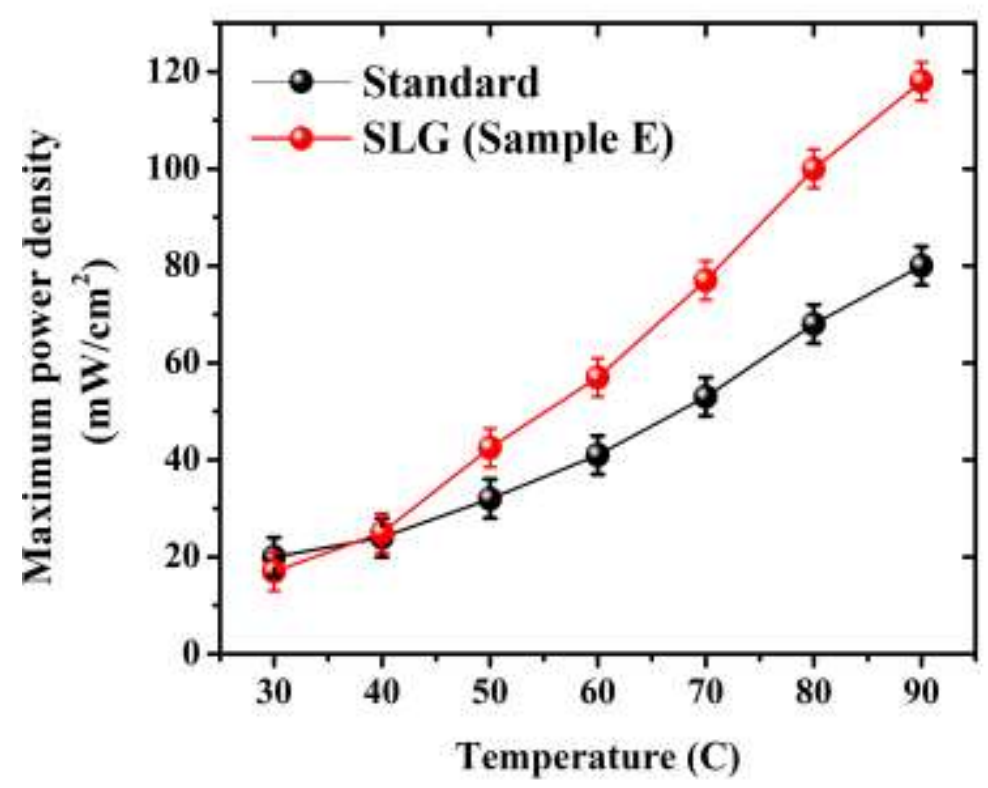

Figure 3. Maximum power density obtained at different temperatures for the standard MEA and SLG.

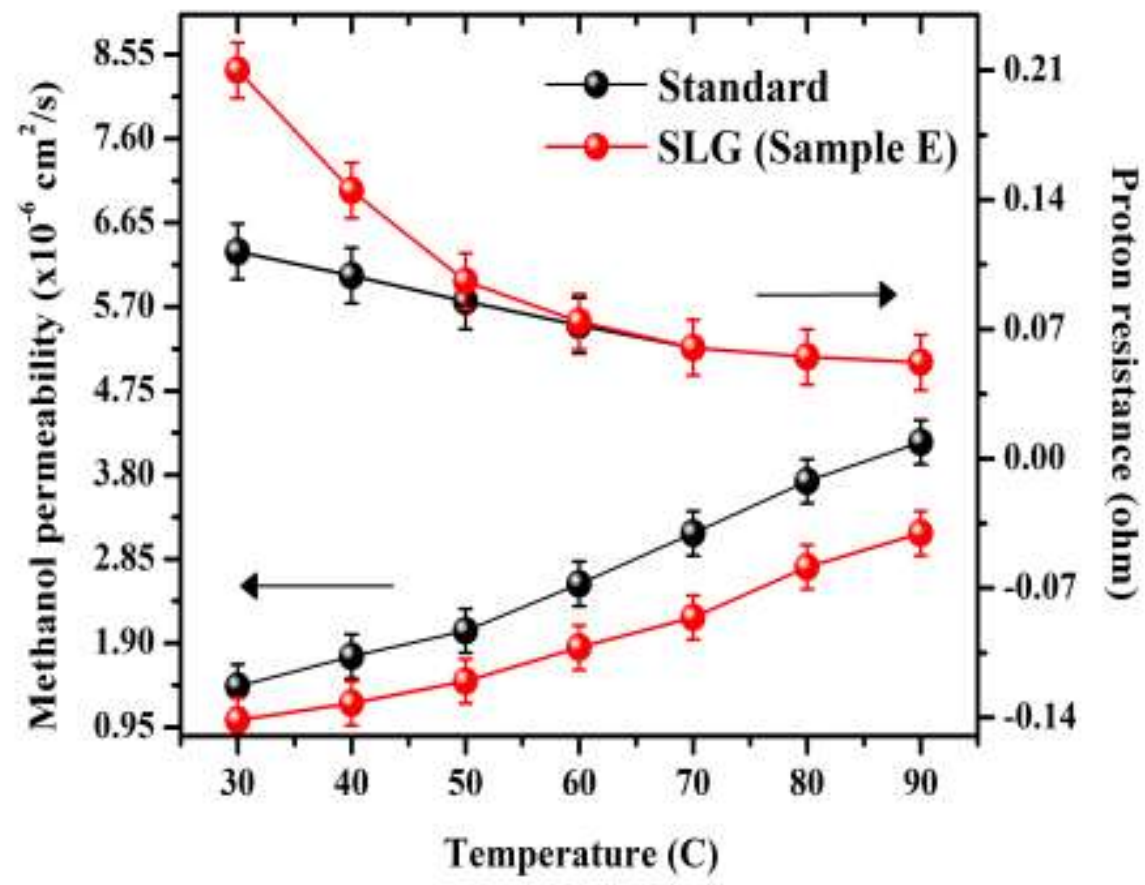

Figure 4. Methanol permeability and proton resistance values obtained at different temperatures for the MEA with standard and SLG. 

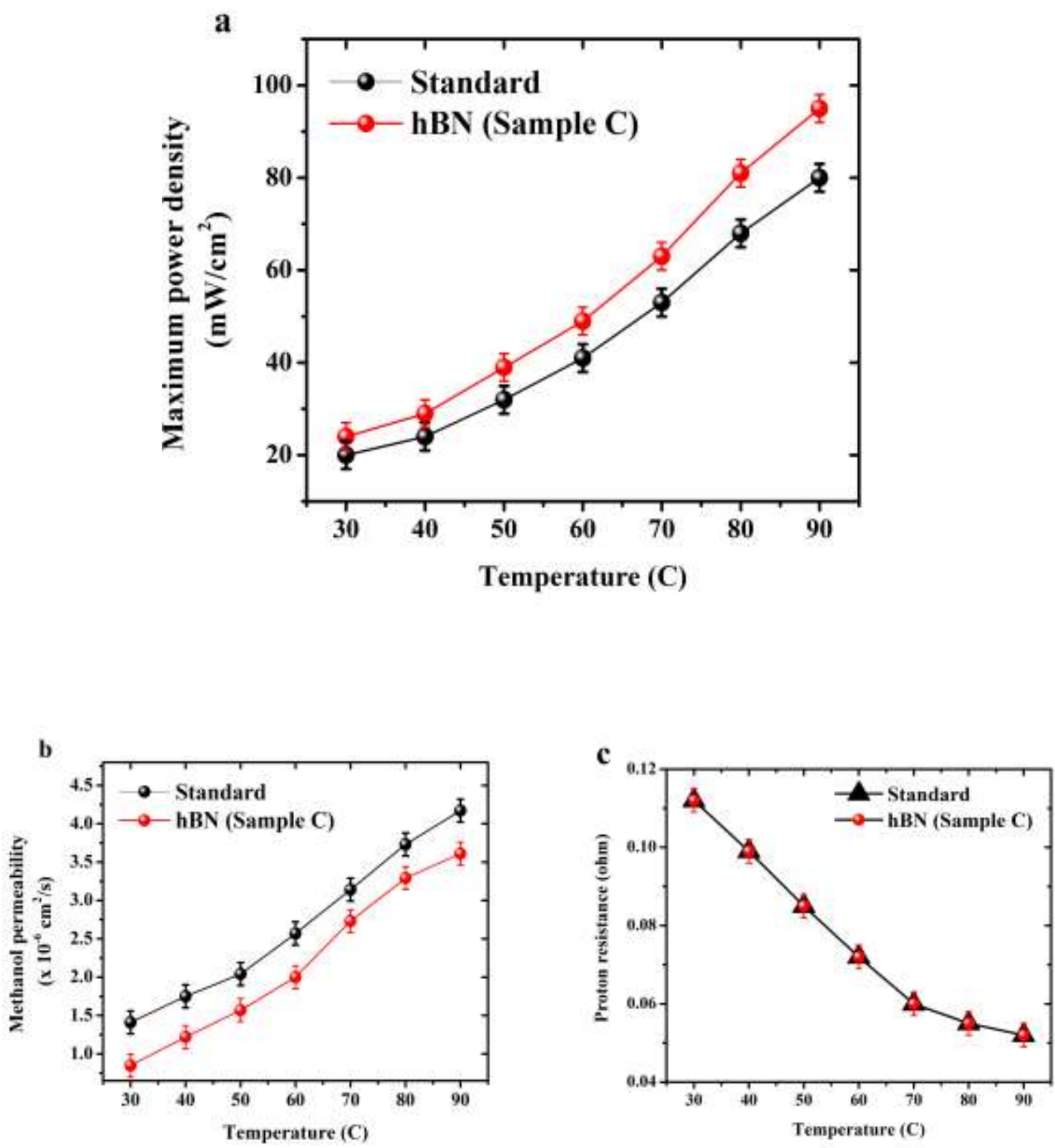

Figure 5. (a) Maximum power density obtained at different temperatures for the standard MEA and hBN (b) Methanol permeability values obtained at different temperatures for the MEA with standard and hBN (c) Proton resistance values obtained at different temperatures for the MEA with standard and hBN. 
Copyright WILEY-VCH Verlag GmbH \& Co. KGaA, 69469 Weinheim, Germany, 2013.

\section{Supporting Information}

2-D Crystals Significantly Enhance the Performance of a Working Fuel Cell

Stuart M. Holmes*, Prabhuraj Balakrishnan, Vasu. S. Kalangi, Xiang Zhang, Pulickel M. Ajayan, Marcelo Lozada-Hidalgo and Rahul R. Nair

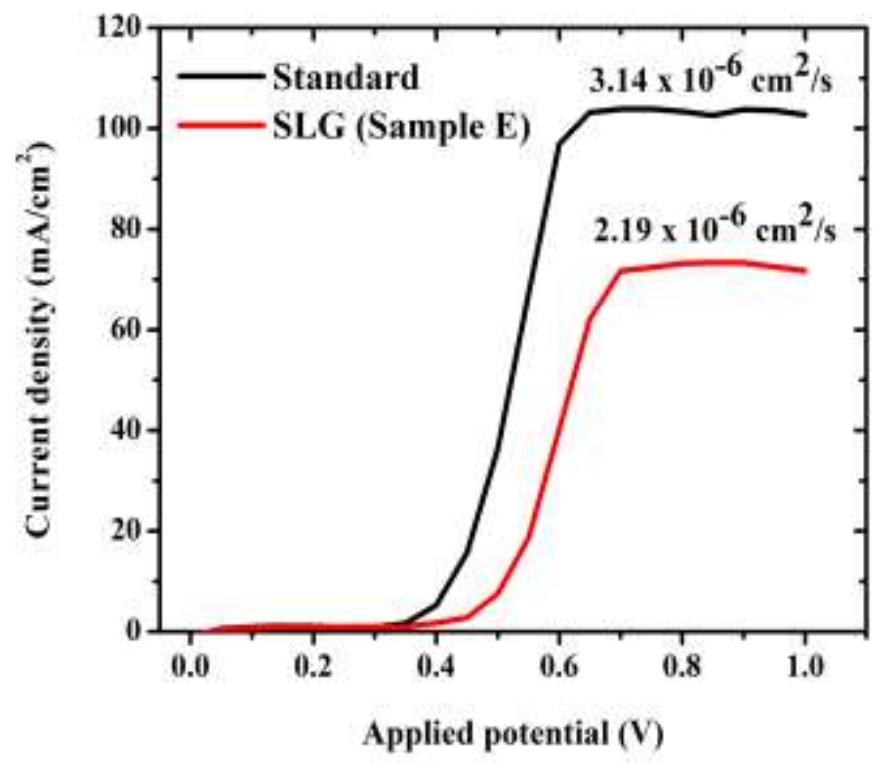

Figure S1. Methanol permeability (linear sweep voltammetry) at $70^{\circ} \mathrm{C}, 1 \mathrm{M}$ methanol conditions.

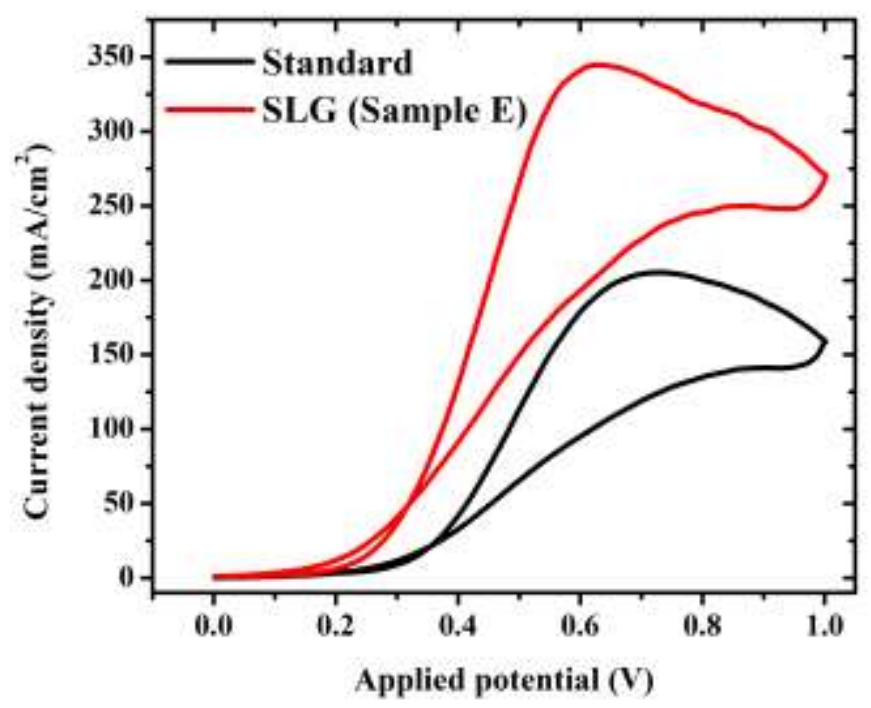

Figure S2. Methanol oxidation reaction (cyclic voltammetry) at $70^{\circ} \mathrm{C}, 1 \mathrm{M}$ methanol. 


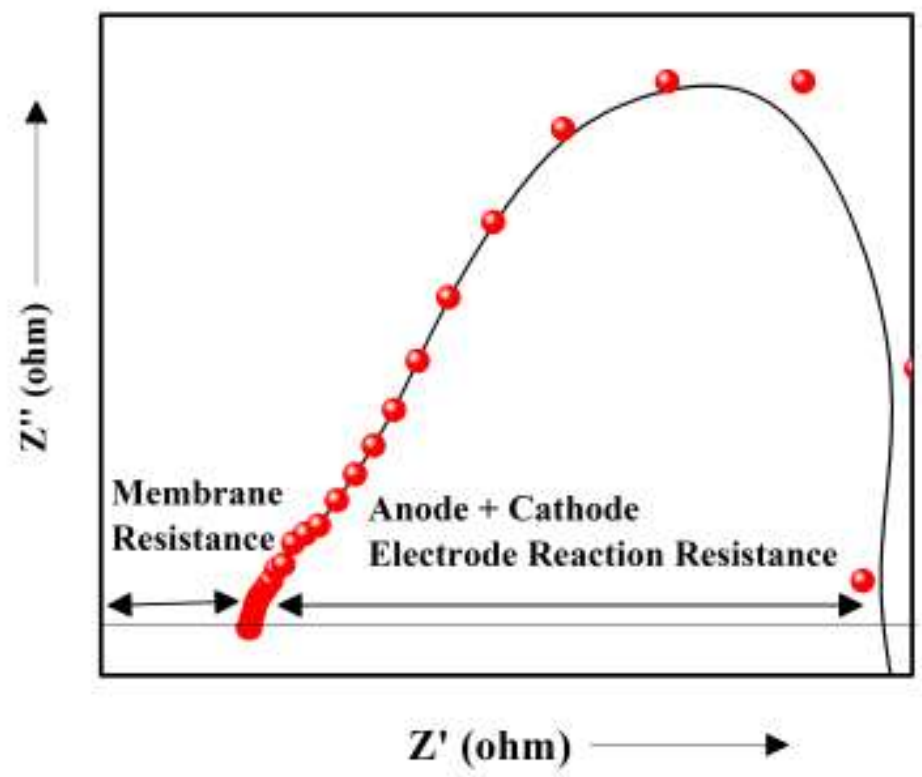

Figure S3. Representation of the information which can be extracted from the impedance plot.

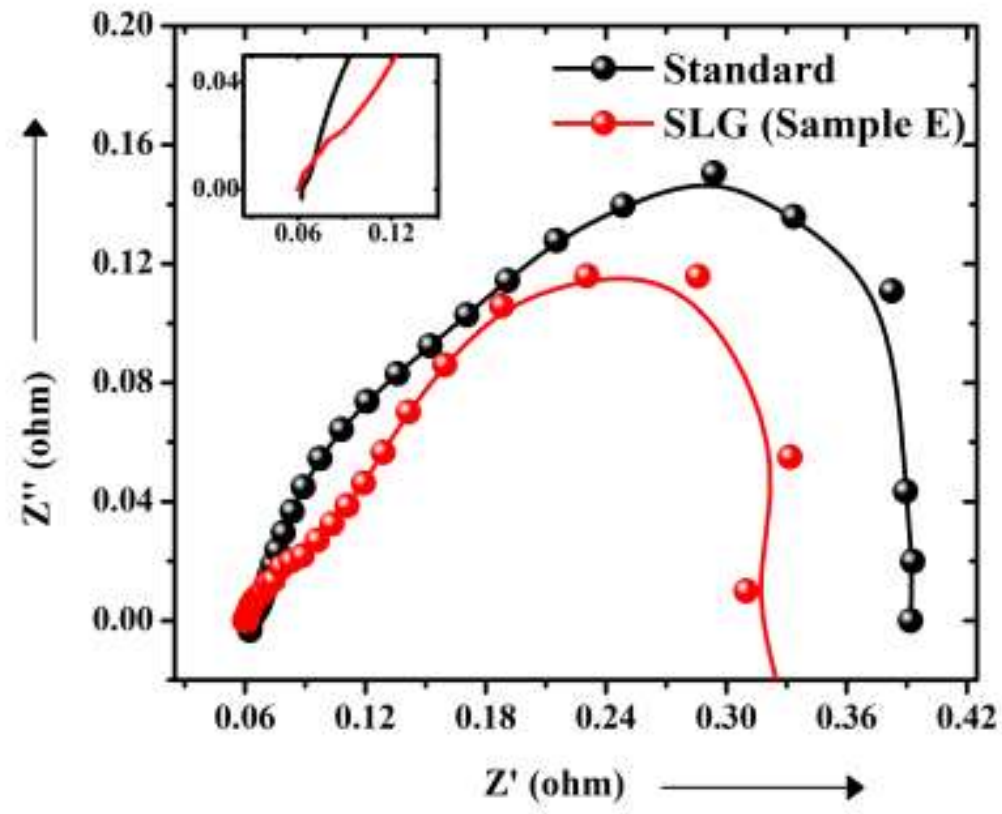

Figure S4. Impedance plot data obtained at $70^{\circ} \mathrm{C}, 1 \mathrm{M}$ methanol, $1 \mathrm{~L} / \mathrm{min}$ of air. 


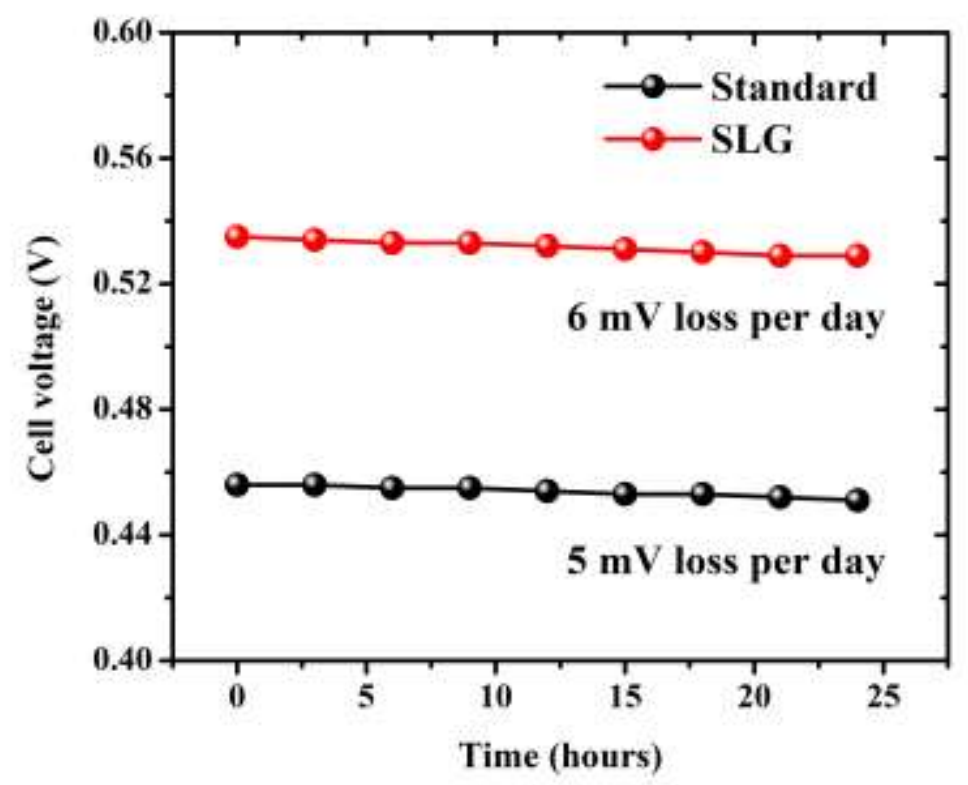

Figure S5. Durability data for standard and SLG in (a) Low current region $\left(50 \mathrm{~mA} / \mathrm{cm}^{2}\right)$.

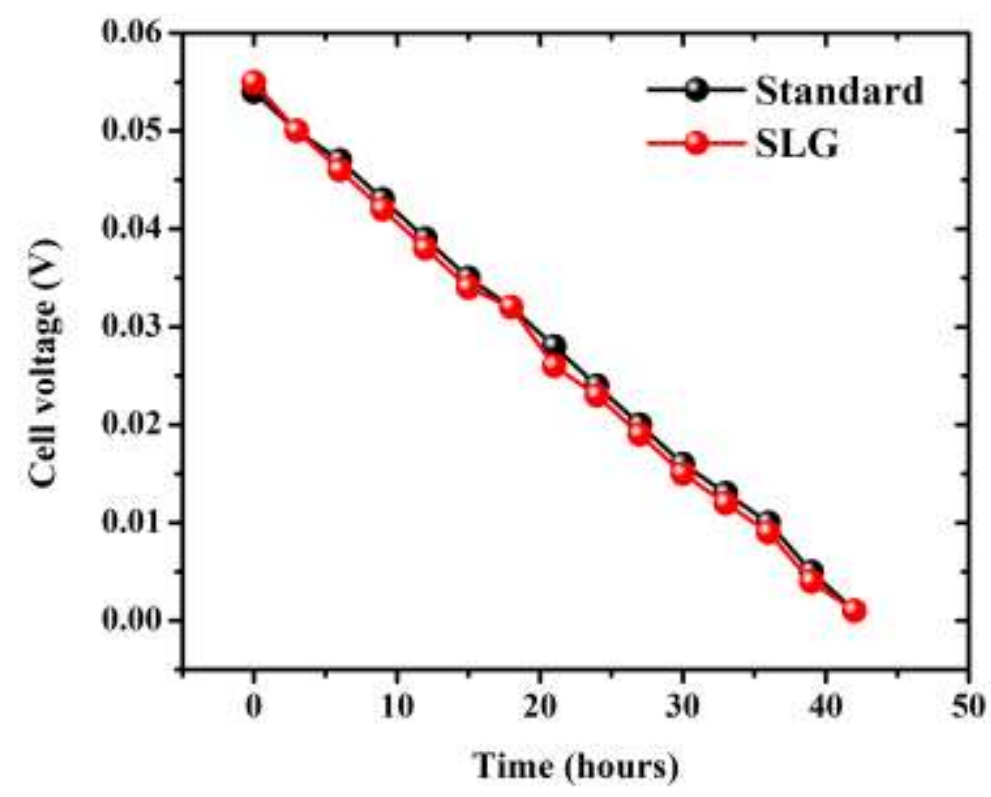

Figure S6. Durability data for standard and SLG in (b) High current density region obtained at $70^{\circ} \mathrm{C}, 1 \mathrm{M}$ methanol and $1 \mathrm{~L} / \mathrm{min}$ of air. 


\section{WILEY-VCH}
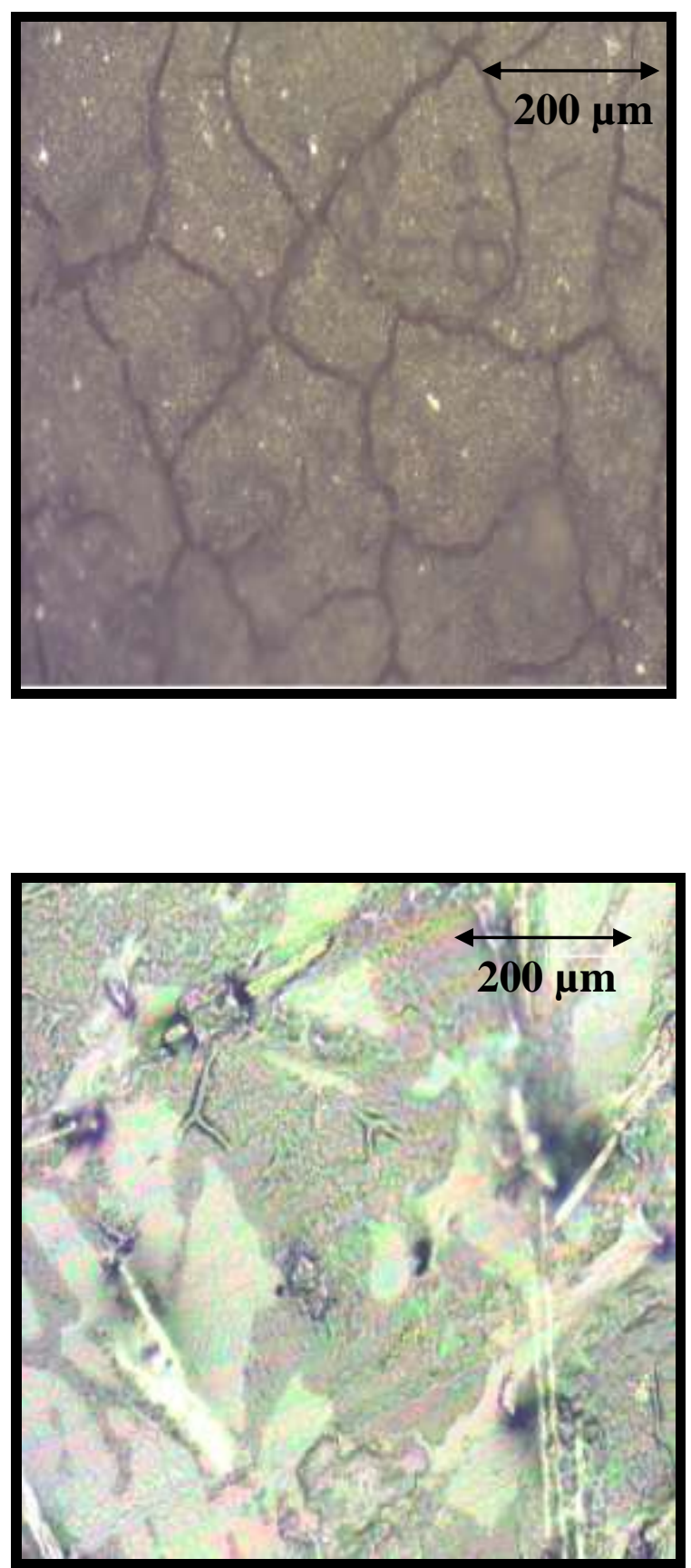

Figure S7. Optical image of electrode before (a) and after (b) CVD graphene deposition. 

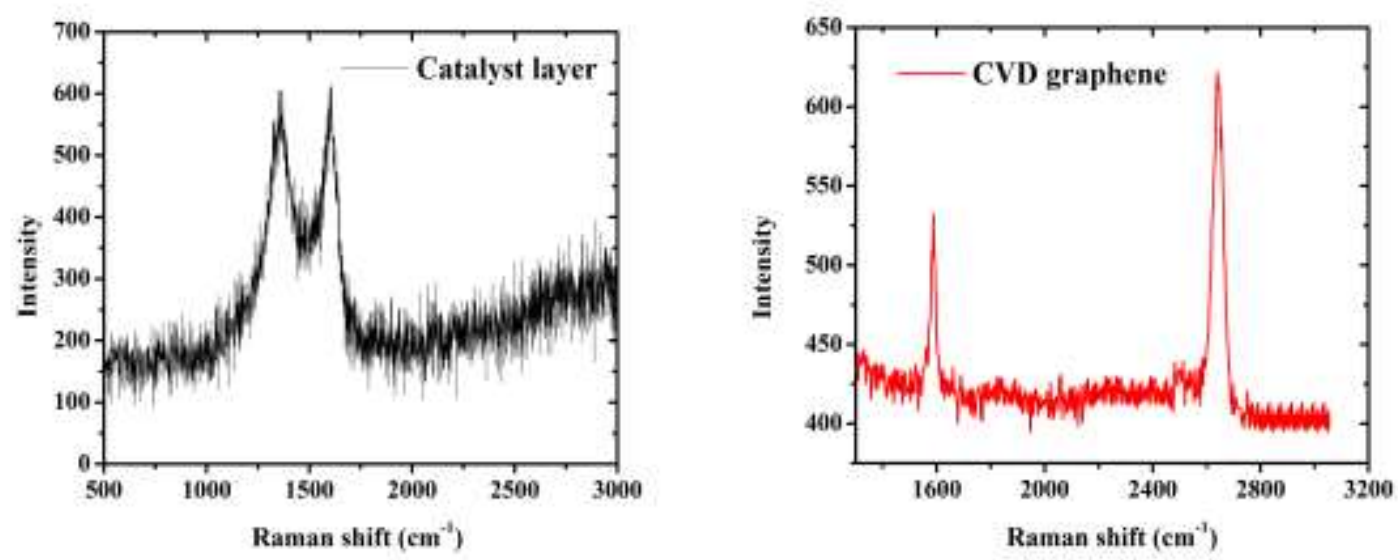

Figure S8. Raman plot of electrode before (a) and after (b) CVD graphene deposition.

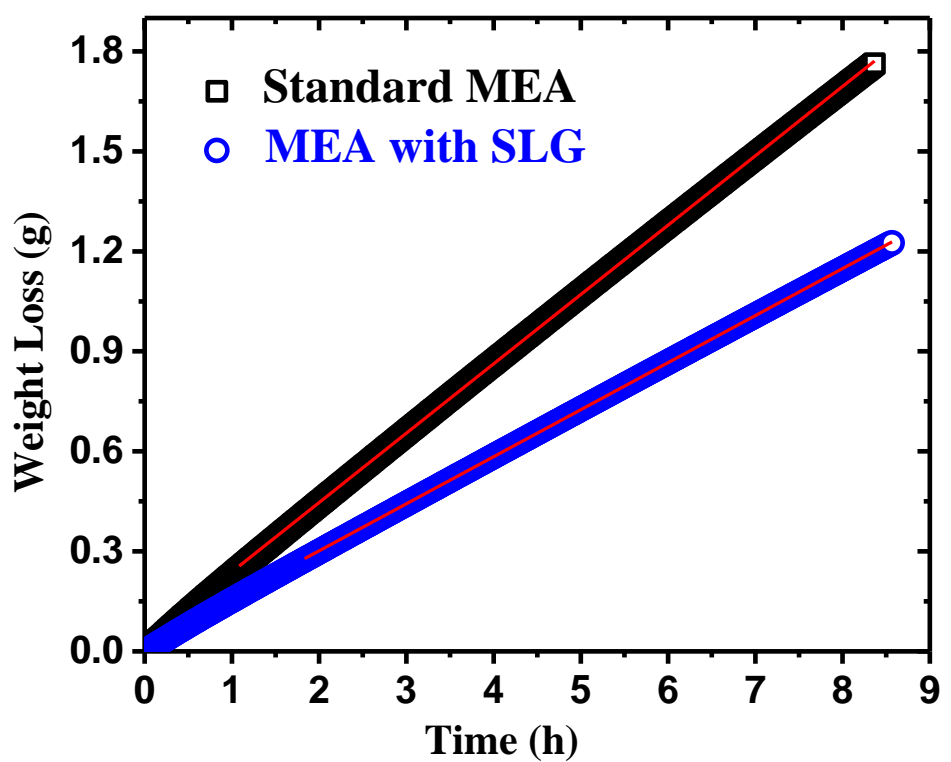

Figure S9. Weight loss from a methanol container sealed with standard MEA and MEA coated with SLG. 


\section{WILEY-VCH}

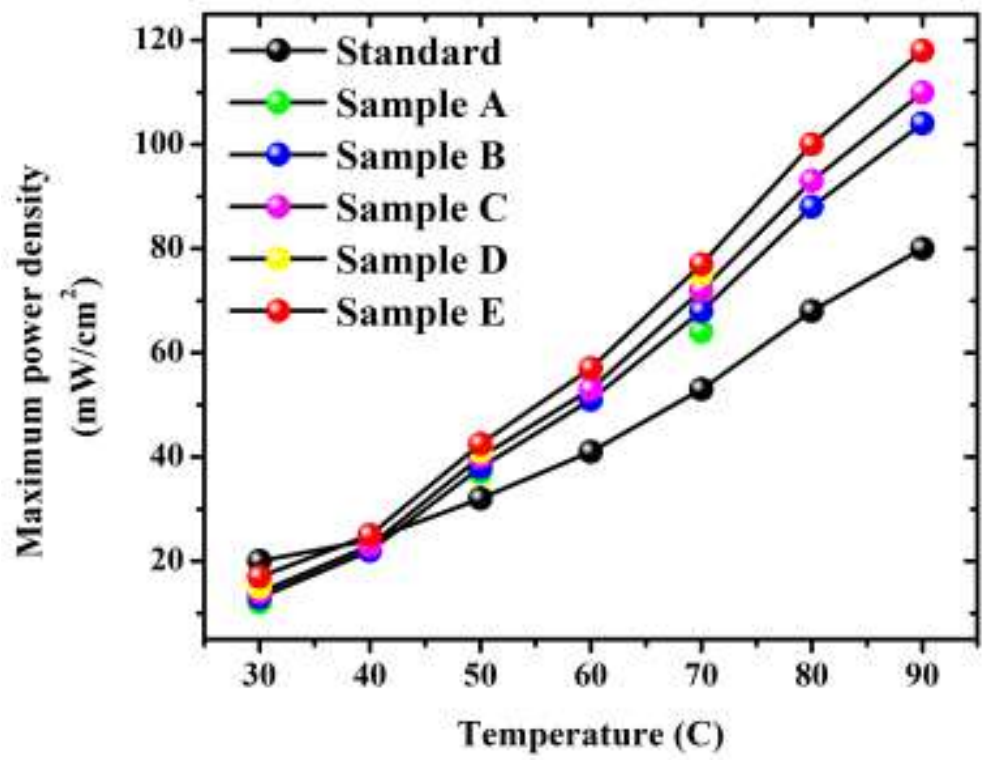

As surface coverage increases, performance is improved.

Figure S10. Maximum power density obtained at different temperatures for the standard MEA and SLG for different samples.

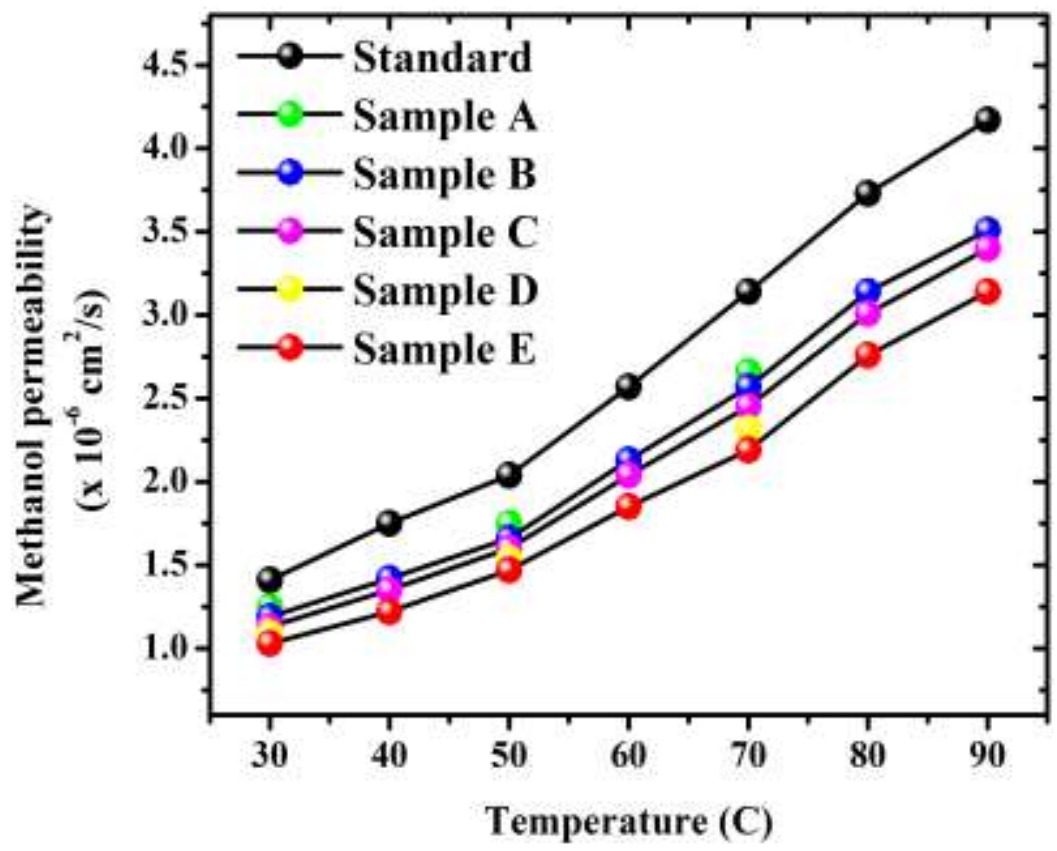

As surface coverage increases, permeability is decreased.

Figure S11. Methanol permeability values obtained at different temperatures for the MEA with standard and SLG for different samples. 


\section{WILEY-VCH}

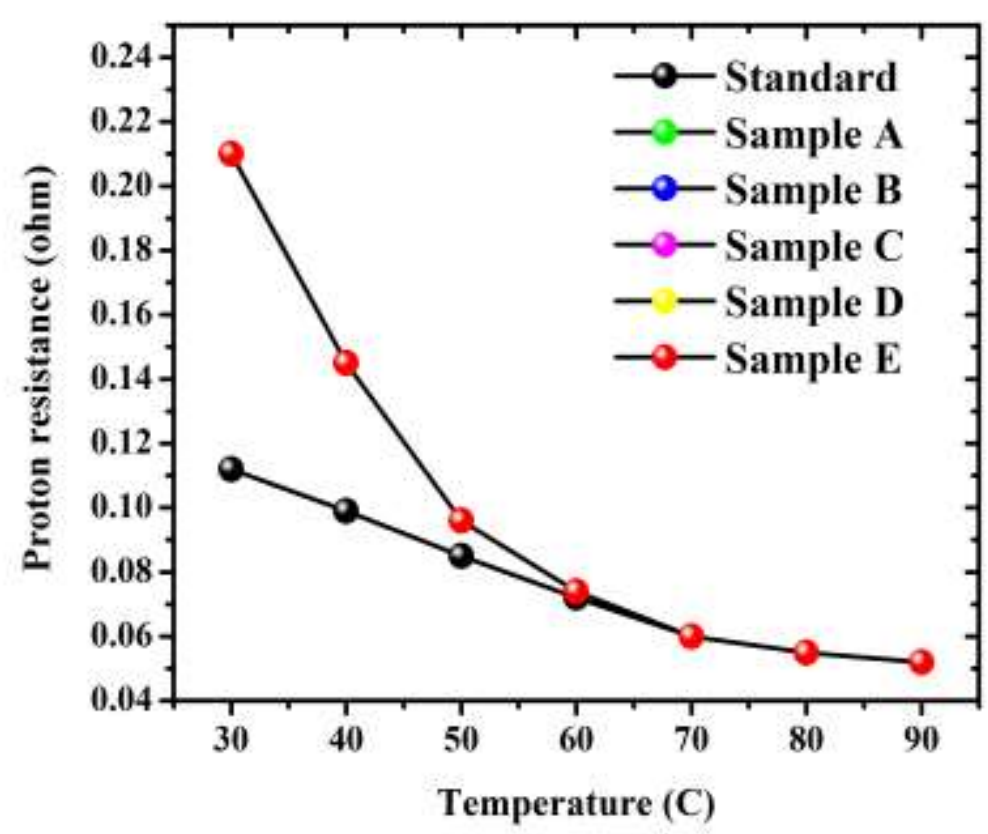

No difference in proton resistance could be found for different samples

Figure S12. Proton resistance values obtained at different temperatures for the MEA with standard and SLG for different samples.

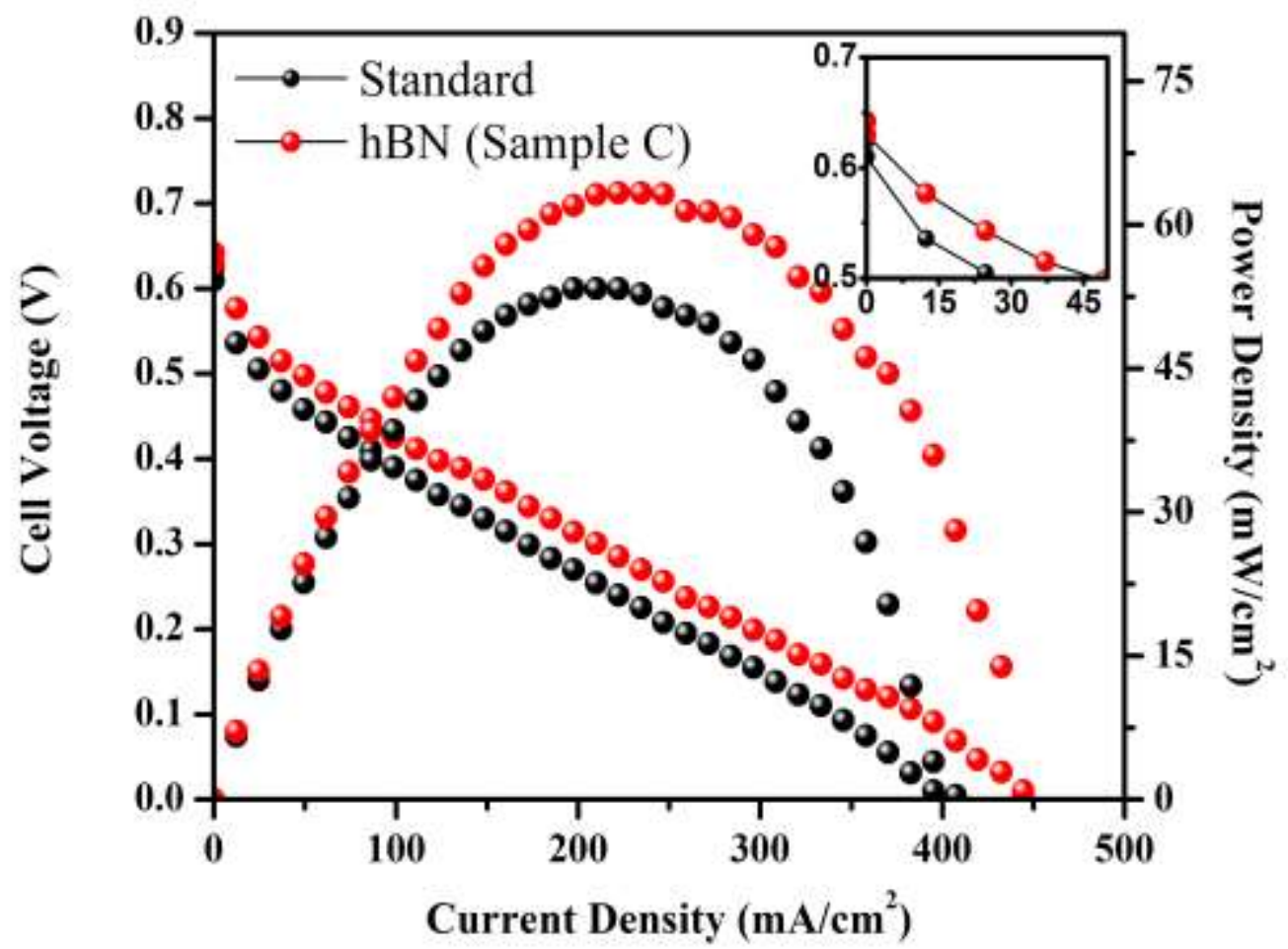

Figure S13. Polarization curve comparison for a standard and MEA with hBN (sample

C) at $70^{\circ} \mathrm{C}, 1 \mathrm{M}$ methanol, $1 \mathrm{~L} / \mathrm{min}$ of air. 


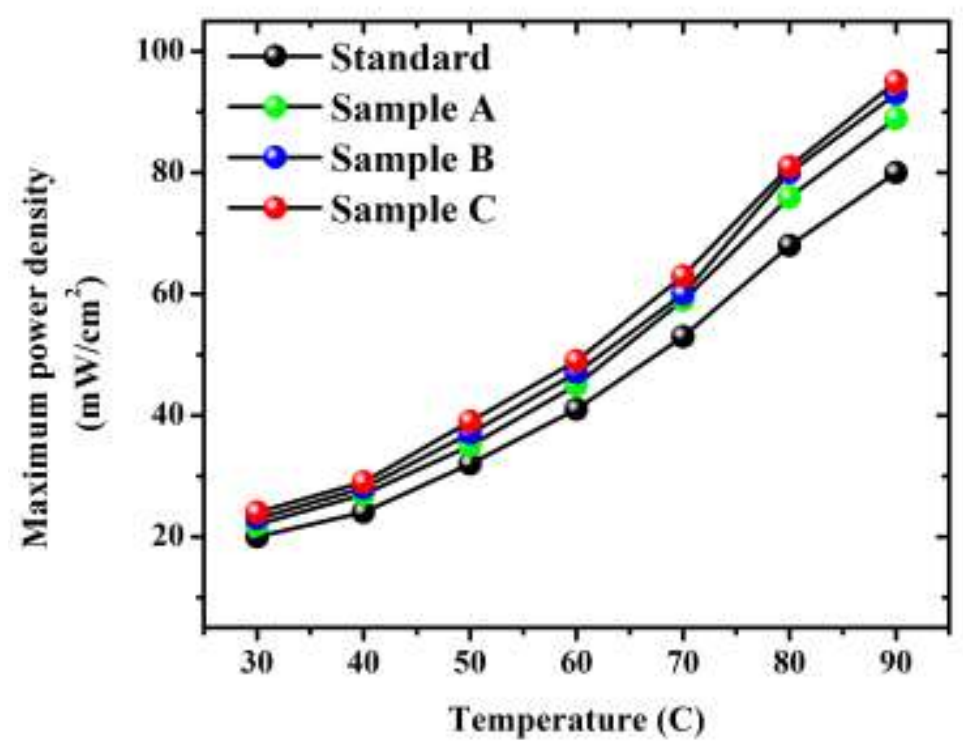

Figure S14. Maximum power density obtained at different temperatures for the standard MEA and hBN for different samples.

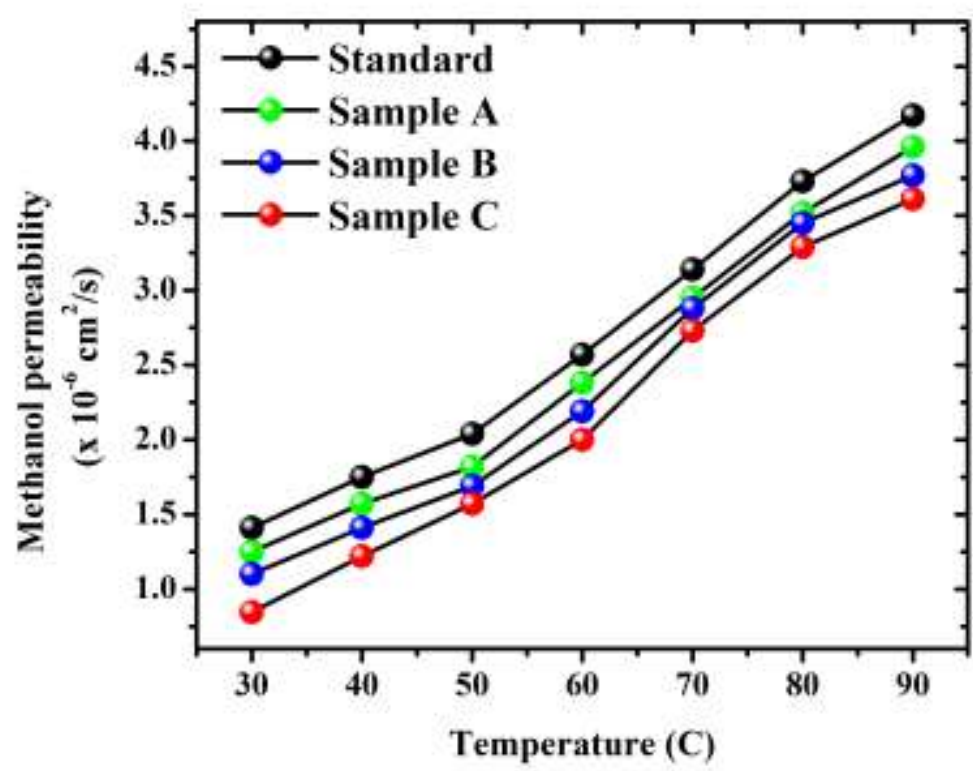

Figure S15. Methanol permeability values obtained at different temperatures for the MEA with standard and hBN for different samples. 


\section{WILEY-VCH}

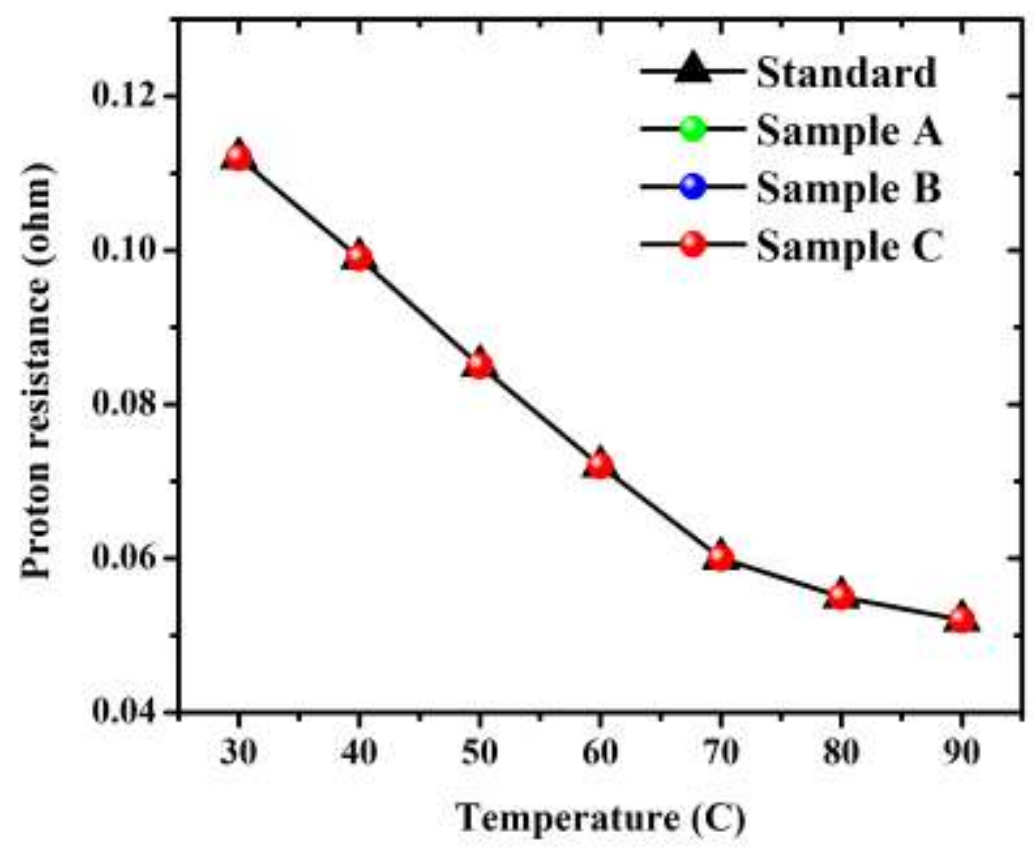

No difference in proton resistance could be found

for different samples

Figure S16. Proton resistance values obtained at different temperatures for the MEA with standard and hBN for different samples.

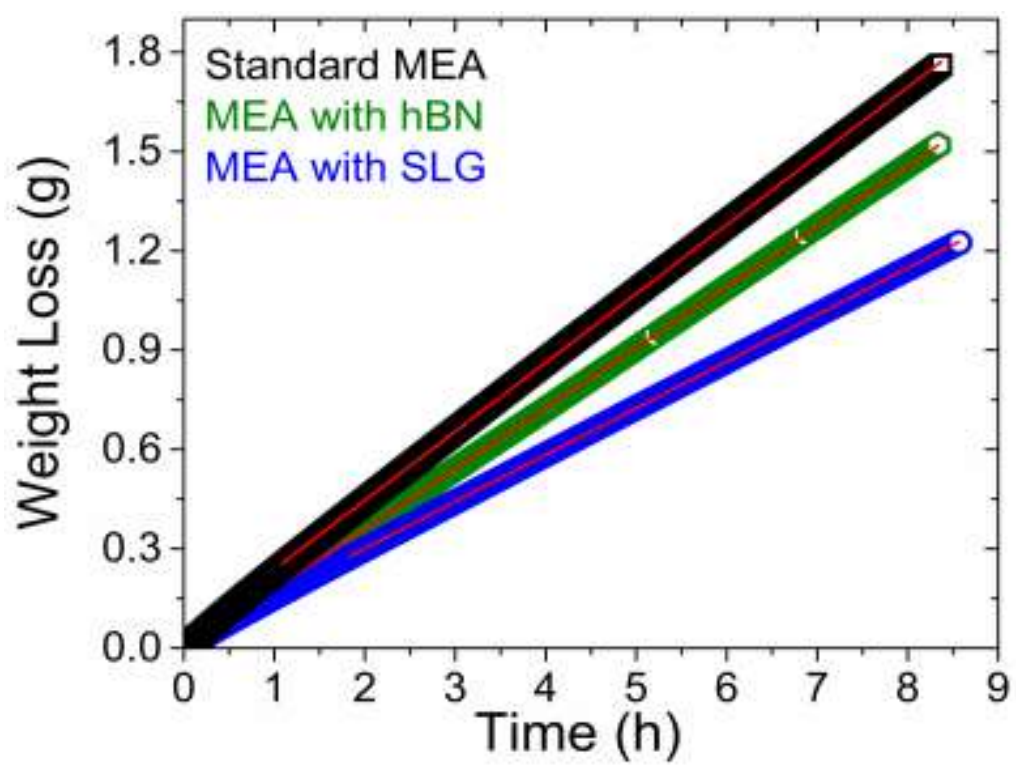

Figure S17. Weight loss from a methanol container sealed with standard MEA and MEA coated with hBN (SLG added for comparison). 


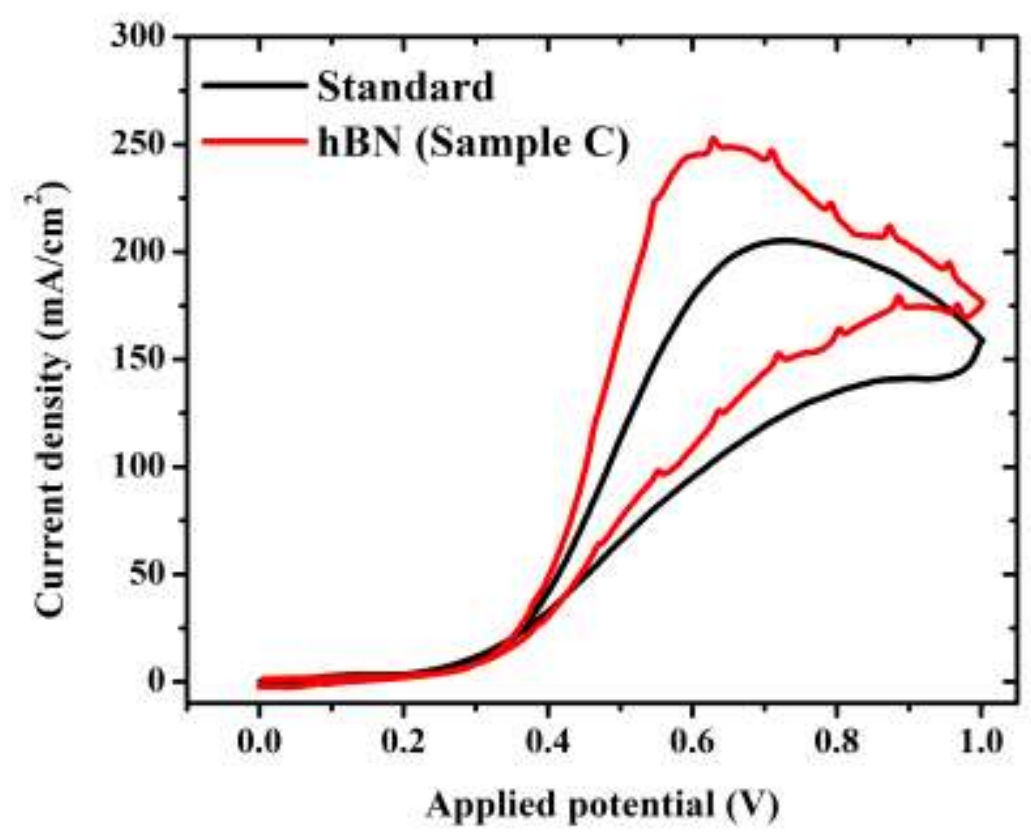

Figure S18. Methanol oxidation reaction (cyclic voltammetry) at $70^{\circ} \mathrm{C}, 1 \mathrm{M}$ methanol. 
Table S1. Effect of temperature on cell performance values for different samples

Maximum power density obtained

$\left[\mathrm{mW} / \mathrm{cm}^{2}\right]$

\begin{tabular}{|c|c|c|c|c|c|c|c|}
\hline & $\begin{array}{l}90 \\
{\left[{ }^{\circ} \mathrm{C}\right]}\end{array}$ & $\begin{array}{l}80 \\
{\left[{ }^{\circ} \mathrm{C}\right]}\end{array}$ & $\begin{array}{l}70 \\
{\left[{ }^{\circ} \mathrm{C}\right]}\end{array}$ & $\begin{array}{l}60 \\
{\left[{ }^{\circ} \mathrm{C}\right]}\end{array}$ & $\begin{array}{l}50 \\
{\left[{ }^{\circ} \mathrm{C}\right]}\end{array}$ & $\begin{array}{l}40 \\
{\left[{ }^{\circ} \mathrm{C}\right]}\end{array}$ & $\begin{array}{l}30 \\
{\left[{ }^{\circ} \mathrm{C}\right]}\end{array}$ \\
\hline Standard & 80 & 68 & 53 & 41 & 32 & 24 & 20 \\
\hline Sample A & & & 64 & & 37 & & 12 \\
\hline Sample B & 104 & 88 & 68 & 51 & 38 & 22 & 13 \\
\hline Sample C & 110 & 93 & 72 & 53 & 40 & 23 & 14 \\
\hline Sample D & & & 75 & & 41 & & 15 \\
\hline Sample E & 118 & 100 & 77 & 57 & 42.5 & 25 & 17 \\
\hline
\end{tabular}


Table S2. Effect of temperature on methanol permeability values for different samples

\begin{tabular}{|c|c|c|c|c|c|c|c|}
\hline \multicolumn{8}{|c|}{$\begin{array}{l}\text { Methanol permeability values } \\
\qquad\left[\mathrm{mA} / \mathrm{cm}^{2}\right]\end{array}$} \\
\hline & $\begin{array}{l}90 \\
{\left[{ }^{\circ} \mathrm{C}\right]}\end{array}$ & $\begin{array}{l}80 \\
{\left[{ }^{\circ} \mathrm{C}\right]}\end{array}$ & $\begin{array}{l}70 \\
{\left[{ }^{\circ} \mathrm{C}\right]}\end{array}$ & $\begin{array}{l}60 \\
{\left[{ }^{\circ} \mathrm{C}\right]}\end{array}$ & $\begin{array}{l}50 \\
{\left[{ }^{\circ} \mathrm{C}\right]}\end{array}$ & $\begin{array}{l}40 \\
{\left[{ }^{\circ} \mathrm{C}\right]}\end{array}$ & $\begin{array}{l}30 \\
{\left[{ }^{\circ} \mathrm{C}\right]}\end{array}$ \\
\hline Standard & 133 & 119 & 100 & 82 & 65 & 56 & 45 \\
\hline Sample A & & & 85 & & 56 & & 40 \\
\hline Sample B & 112 & 100 & 82 & 68 & 53 & 45 & 38 \\
\hline Sample C & 108 & 96 & 78 & 65 & 51 & 43 & 36 \\
\hline Sample D & & & 74 & & 49 & & 35 \\
\hline Sample E & 100 & 88 & 70 & 59 & 47 & 39 & 33 \\
\hline
\end{tabular}


Table S3. Effect of temperature on proton resistance values for different samples

\begin{tabular}{|c|c|c|c|c|c|c|c|}
\hline \multicolumn{8}{|c|}{$\begin{array}{c}\text { Proton resistance } \\
{[\mathrm{ohm}]}\end{array}$} \\
\hline & $\begin{array}{l}90 \\
{\left[{ }^{\circ} \mathrm{C}\right]}\end{array}$ & $\begin{array}{l}80 \\
{\left[{ }^{\circ} \mathrm{C}\right]}\end{array}$ & $\begin{array}{l}70 \\
{\left[{ }^{\circ} \mathrm{C}\right]}\end{array}$ & $\begin{array}{l}60 \\
{\left[{ }^{\circ} \mathrm{C}\right]}\end{array}$ & $\begin{array}{l}50 \\
{\left[{ }^{\circ} \mathrm{C}\right]}\end{array}$ & $\begin{array}{l}40 \\
{\left[{ }^{\circ} \mathrm{C}\right]}\end{array}$ & $\begin{array}{l}30 \\
{\left[{ }^{\circ} \mathrm{C}\right]}\end{array}$ \\
\hline Standard & 0.052 & 0.055 & 0.060 & 0.072 & 0.085 & 0.099 & 0.112 \\
\hline Sample A & & & 0.060 & & 0.096 & & 0.210 \\
\hline Sample B & 0.052 & 0.055 & 0.060 & 0.074 & 0.096 & 0.145 & 0.210 \\
\hline Sample C & 0.052 & 0.055 & 0.060 & 0.074 & 0.096 & 0.145 & 0.210 \\
\hline Sample D & & & 0.060 & & 0.096 & & 0.210 \\
\hline Sample E & 0.052 & 0.055 & 0.060 & 0.074 & 0.096 & 0.145 & 0.210 \\
\hline
\end{tabular}


Table S4. Effect of temperature on cell performance values for standard and hBN samples

\begin{tabular}{|c|c|c|c|c|c|c|c|}
\hline \multicolumn{8}{|c|}{$\begin{array}{l}\text { Maximum power density obtained } \\
\qquad\left[\mathrm{mW} / \mathrm{cm}^{2}\right]\end{array}$} \\
\hline & $\begin{array}{l}90 \\
{\left[{ }^{\circ} \mathrm{C}\right]}\end{array}$ & $\begin{array}{l}80 \\
{\left[{ }^{\circ} \mathrm{C}\right]}\end{array}$ & $\begin{array}{l}70 \\
{\left[{ }^{\circ} \mathrm{C}\right]}\end{array}$ & $\begin{array}{l}60 \\
{\left[{ }^{\circ} \mathrm{C}\right]}\end{array}$ & $\begin{array}{l}50 \\
{\left[{ }^{\circ} \mathrm{C}\right]}\end{array}$ & $\begin{array}{l}40 \\
{\left[{ }^{\circ} \mathrm{C}\right]}\end{array}$ & $\begin{array}{l}30 \\
{\left[{ }^{\circ} \mathrm{C}\right]}\end{array}$ \\
\hline Standard & 80 & 68 & 53 & 41 & 32 & 24 & 20 \\
\hline Sample A & 89 & 76 & 59 & 45 & 35 & 27 & 22 \\
\hline Sample B & 93 & 80 & 60 & 47 & 37 & 28 & 23 \\
\hline Sample C & 95 & 81 & 63 & 49 & 39 & 29 & 24 \\
\hline
\end{tabular}

Table S5. Effect of temperature on methanol permeability values for standard and hBN samples 
Maximum power density obtained $\left[\mathrm{mW} / \mathrm{cm}^{2}\right]$

\begin{tabular}{llllllll}
\hline & $\begin{array}{l}90 \\
{\left[{ }^{\circ} \mathrm{C}\right]}\end{array}$ & $\begin{array}{l}80 \\
{\left[{ }^{\circ} \mathrm{C}\right]}\end{array}$ & $\begin{array}{l}70 \\
{\left[{ }^{\circ} \mathrm{C}\right]}\end{array}$ & $\begin{array}{l}60 \\
{\left[{ }^{\circ} \mathrm{C}\right]}\end{array}$ & $\begin{array}{l}50 \\
{\left[{ }^{\circ} \mathrm{C}\right]}\end{array}$ & $\begin{array}{l}40 \\
{\left[{ }^{\circ} \mathrm{C}\right]}\end{array}$ & $\begin{array}{l}30 \\
{\left[{ }^{\circ} \mathrm{C}\right]}\end{array}$ \\
\hline Standard & 133 & 119 & 100 & 82 & 65 & 56 & 45 \\
Sample A & 126 & 112 & 94 & 76 & 58 & 50 & 40 \\
Sample B & 120 & 110 & 91 & 70 & 54 & 45 & 35 \\
& & & & & & & \\
Sample C & 115 & 105 & 87 & 64 & 50 & 39 & 27 \\
\hline
\end{tabular}

Table S6. Effect of temperature on proton conductivity values for standard and hBN samples

Proton resistance

[ohm]

\begin{tabular}{llllllll}
\hline & $\begin{array}{l}90 \\
{\left[{ }^{\circ} \mathrm{C}\right]}\end{array}$ & $\begin{array}{l}80 \\
{\left[{ }^{\circ} \mathrm{C}\right]}\end{array}$ & $\begin{array}{l}70 \\
{\left[{ }^{\circ} \mathrm{C}\right]}\end{array}$ & $\begin{array}{l}60 \\
{\left[{ }^{\circ} \mathrm{C}\right]}\end{array}$ & $\begin{array}{l}50 \\
{\left[{ }^{\circ} \mathrm{C}\right]}\end{array}$ & $\begin{array}{l}40 \\
{\left[{ }^{\circ} \mathrm{C}\right]}\end{array}$ & $\begin{array}{l}30 \\
{\left[{ }^{\circ} \mathrm{C}\right]}\end{array}$ \\
\hline Standard & 0.052 & 0.055 & 0.060 & 0.072 & 0.085 & 0.099 & 0.112 \\
& & & & & & & \\
Sample A & 0.052 & 0.055 & 0.060 & 0.072 & 0.085 & 0.099 & 0.112 \\
& & & & & & & \\
Sample B & 0.053 & 0.056 & 0.060 & 0.073 & 0.086 & 0.099 & 0.112
\end{tabular}




\section{WILEY-VCH}

$\begin{array}{llllllll}\text { Sample C } & 0.053 & 0.055 & 0.060 & 0.072 & 0.085 & 0.099 & 0.113\end{array}$ 